\title{
Arctic Ocean stratification set by sea level and freshwater inputs since the last ice age
}

\author{
Jesse R. Farmer $\mathbb{1}^{1,2} \llbracket$, Daniel M. Sigman $\mathbb{1}^{1}$, Julie Granger ${ }^{3}$, Ona M. Underwood', François Fripiat $\mathbb{B}^{2,4}$, \\ Thomas M. Cronin ${ }^{(5)}$, Alfredo Martínez-García $\mathbb{1}^{2}{ }^{2}$ and Gerald H. Haug ${ }^{2,6}$
}

\begin{abstract}
Salinity-driven density stratification of the upper Arctic Ocean isolates sea-ice cover and cold, nutrient-poor surface waters from underlying warmer, nutrient-rich waters. Recently, stratification has strengthened in the western Arctic but has weakened in the eastern Arctic; it is unknown if these trends will continue. Here we present foraminifera-bound nitrogen isotopes from Arctic Ocean sediments since 35,000 years ago to reconstruct past changes in nutrient sources and the degree of nutrient consumption in surface waters, the latter reflecting stratification. During the last ice age and early deglaciation, the Arctic was dominated by Atlantic-sourced nitrate and incomplete nitrate consumption, indicating weaker stratification. Starting at 11,000 years ago in the western Arctic, there is a clear isotopic signal of Pacific-sourced nitrate and complete nitrate consumption associated with the flooding of the Bering Strait. These changes reveal that the strong stratification of the western Arctic relies on low-salinity inflow through the Bering Strait. In the central Arctic, nitrate consumption was complete during the early Holocene, then declined after 5,000 years ago as summer insolation decreased. This sequence suggests that precipitation and riverine freshwater fluxes control the stratification of the central Arctic Ocean. Based on these findings, ongoing warming will cause strong stratification to expand into the central Arctic, slowing the nutrient supply to surface waters and thus limiting future phytoplankton productivity.
\end{abstract}

T he Arctic climate system is changing rapidly ${ }^{1}$, as exemplified by dramatic declines in sea-ice extent, concentration and thickness over the past four decades ${ }^{1,2}$. Resultant increases in the area and seasonal duration of open water are associated with increased Arctic Ocean biological productivity ${ }^{3}$. Climate model simulations suggest that the Arctic Ocean could be seasonally ice-free within decades ${ }^{4}$, with expected impacts on the biological productivity $^{5-8}$ of the Arctic Ocean and climate ${ }^{1}$.

Density stratification from salinity is fundamental to Arctic Ocean circulation, sea-ice cover and productivity ${ }^{9}$. Cold and fresh surface waters of the polar mixed layer (PML) are separated from warmer and saltier subsurface waters of Atlantic and Pacific origin by the "halocline", which isolates the PML from subsurface heat and nutrients. Excess precipitation relative to evaporation, river discharge and the advection of low-salinity ocean waters across the Bering Strait are each thought to contribute to the Arctic Ocean's salinity stratification ${ }^{10-12}$. Over recent decades, this stratification has weakened in the eastern Arctic (Eurasian Basin) and strengthened in the western Arctic (Amerasian Basin) ${ }^{13,14}$. Whether or not these trends will continue into the future-and how sea-ice coverage and productivity will be impacted-is uncertain ${ }^{5-8,15,16}$.

To gain insight into past Arctic Ocean stratification, we reconstructed the sources and degree of biological consumption of nitrogen $(\mathrm{N})$, the limiting nutrient for summertime Arctic productivity ${ }^{5,17}$, at three locations in the open (that is, off-shelf) western and central Arctic Ocean over the past 35,000 years (Fig. 1a). We analysed the $\mathrm{N}$ isotopic composition of organic matter (expressed as $\left.\delta^{15} \mathrm{~N}=\left[\left({ }^{15} \mathrm{~N} /{ }^{14} \mathrm{~N}\right)_{\text {sample }} /\left({ }^{15} \mathrm{~N} /{ }^{14} \mathrm{~N}\right)_{\text {air }}-1\right] \times 1,000\right)$ within the shell walls of the planktonic foraminifer Neogloboquadrina pachyderma (hereafter, $\delta^{15} \mathrm{~N}_{N . p .}$ ). The $\delta^{15} \mathrm{~N}_{\text {N.p. }}$ value reflects the $\delta^{15} \mathrm{~N}$ of organic matter produced in surface waters, which itself depends on the $\delta^{15} \mathrm{~N}$ of the subsurface nitrogen supply (which is as nitrate, $\mathrm{NO}_{3}^{-}$) and the degree of nitrate consumption, that is, the summertime drawdown of nitrate as a proportion of the annual nitrate supply (Methods). In contrast to bulk-sediment $\delta^{15} \mathrm{~N}, \delta^{15} \mathrm{~N}_{\text {N.p. }}$ is protected from early bacterial diagenesis and terrestrial organic matter contamination (Extended Data Fig. 1).

\section{Arctic hydrography and nitrogen isotopes}

Water and nitrate are supplied to the upper Arctic Ocean from distinct Atlantic and Pacific sources (Fig. 1a). Atlantic-sourced halocline water (AHW) originates from inflow through the Fram Strait and the Barents Sea and dominates the eastern and central Arctic Ocean up to the Mendeleev Ridge in the Amerasian Basin ${ }^{5,18-20}$. In the far western Arctic Ocean, AHW is covered by fresher Pacific-sourced halocline water (PHW), which forms in the Chukchi Sea from inflow across the approximately 50-m-deep Bering Strait ${ }^{5,21}$. The northern boundary of PHW is at the Mendeleev Ridge today ${ }^{18}$ (Fig. 1a) but appears to shift with the Arctic Oscillation, having reached the Lomonosov Ridge in the $1980 \mathrm{~s}^{22}$.

Salinity-driven density stratification determines two critical aspects of Arctic Ocean biological nitrate consumption. First, the stratification constrains the upward flux of nitrate to the PML, which occurs mostly in the winter ${ }^{23}$. Second, the stratification sets the depth of the summertime $\mathrm{PML}^{24}$ relative to the depth of the euphotic zone, which impacts the light conditions for phytoplankton. These features are illustrated by comparing the summertime PML characteristics between the Amerasian and Eurasian basins (Fig. 1b). In the Amerasian Basin, a thin $(\leq 10 \mathrm{~m})^{24}$, low-salinity PML with near-zero nitrate concentration overlies the PHW,

'Department of Geosciences, Princeton University, Princeton, NJ, USA. ${ }^{2}$ Max Planck Institute for Chemistry, Mainz, Germany. ${ }^{3}$ Department of Marine Sciences, University of Connecticut, Groton, CT, USA. ${ }^{4}$ Department of Geosciences, Environment and Society, Université Libre de Bruxelles, Brussels, Belgium. ${ }^{5}$ Florence Bascom Geoscience Center, US Geological Survey, Reston, VA, USA. ${ }^{6}$ Department of Earth Sciences, ETH Zürich, Zurich, Switzerland. 凶e-mail: jesse.farmer@princeton.edu 


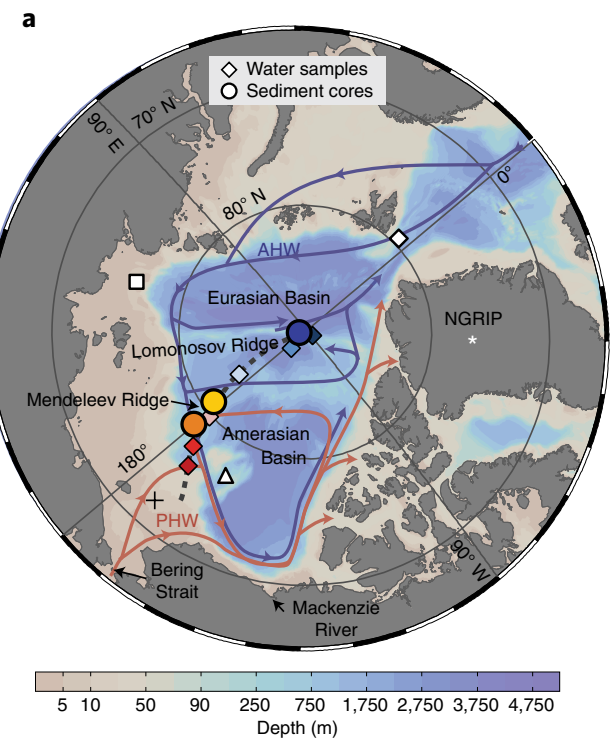

b

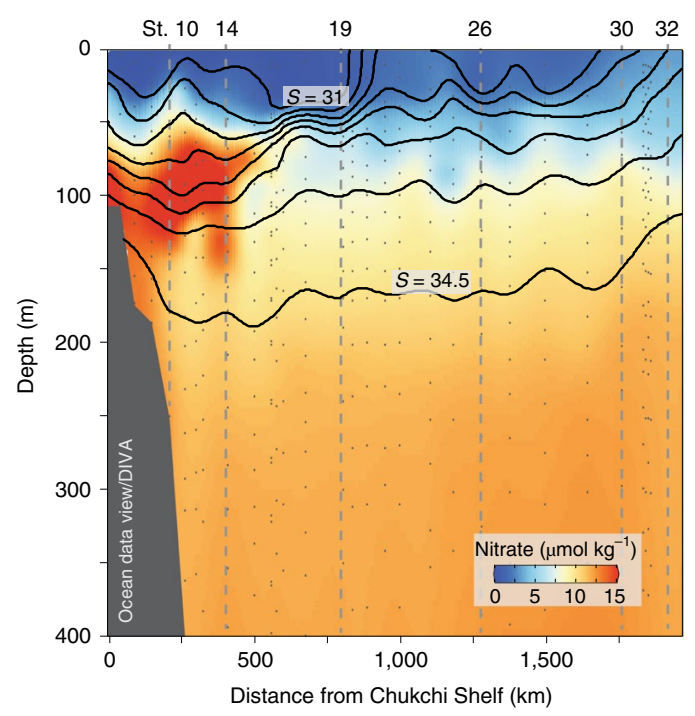

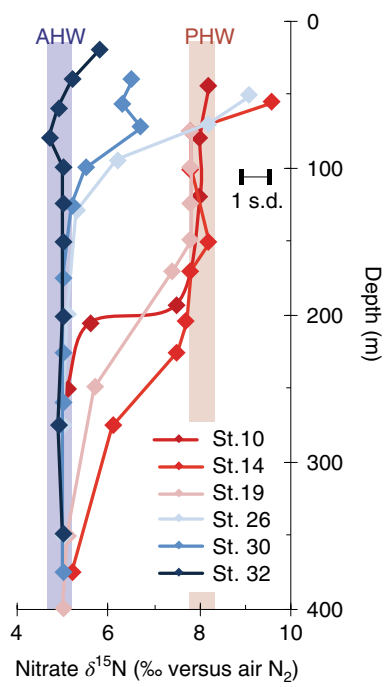

Fig. 1 | Arctic Ocean study locations, hydrography and nitrate distributions. a, Schematic circulation of AHW (in blue) and PHW (in pale red) ${ }^{18}$. The coloured circles and diamonds indicate sediment cores and water-column nitrate $\delta^{15} \mathrm{~N}$ profiles, respectively. The white asterisk denotes the location of the NGRIP ice core ${ }^{45}$; the white diamond, square and triangle and the black cross denote the locations of Holocene sea-ice reconstructions (Extended Data Fig. 2). b, Cross-section along the grey dashed line in a of nitrate concentration (coloured) and salinity S (black contours, interval 0.5 psu) from AOS94 data $^{19}$. Vertical dashed lines indicate the locations of nitrate isotope data from ARC01 stations 10,14, 19, 26, 30 and 32 (in c). c, Arctic Ocean nitrate $\delta^{15} \mathrm{~N}$ from ARC01 (for colour code see a). Vertical blue and red shading indicates the average $\delta^{15} \mathrm{~N}$ values for AHW and PHW nitrate, respectively. The error bar is the average measurement 1 s.d. (Methods). Panels $\mathbf{a}$ and $\mathbf{b}$ are plotted using ODV ${ }^{51}$.

reflecting the weakness of wintertime nitrate resupply across the strong salinity gradient ${ }^{5,17,20,21,23}$. By contrast, the salinity gradient in the Eurasian Basin is less extreme. Accordingly, the Eurasian Basin summertime PML is deeper $(\sim 20 \mathrm{~m})^{24}$, and PML nitrate concentrations overlying the AHW are higher $(3-10 \mu \mathrm{M})$, reflecting the higher nitrate flux across the weaker halocline ${ }^{17,23}$.

AHW and PHW differ in their nitrate characteristics. In AHW, nitrate occurs at a concentration of $\sim 10 \mu \mathrm{M}$ and with a $\delta^{15} \mathrm{~N}$ of $5 \%$ (Fig. 1c), equivalent to high-latitude North Atlantic subsurface source waters ${ }^{25,26}$. By contrast, PHW exhibits a higher nitrate concentration of $\sim 15 \mu \mathrm{M}$ and a $\delta^{15} \mathrm{~N}$ of $8 \%$ (Fig. 1c). The PHW nitrate $\delta^{15} \mathrm{~N}$ reflects that of North Pacific nitrate $(\sim 6.5 \% 0)^{27}$, with further isotopic enrichment by organic matter regeneration and benthic nitrogen loss on the Bering, Chukchi and East Siberian sea shelves ${ }^{26-29}$.

The origin of the nitrate (Atlantic versus Pacific) and the degree of nitrate consumption in the PML both affect the $\delta^{15} \mathrm{~N}_{\text {N.p. }}$. Based on previous work, the $\delta^{15} \mathrm{~N}_{\text {N.p. }}$ is $2 \%$ higher than the $\delta^{15} \mathrm{~N}$ of nitrate consumed in the euphotic zone ${ }^{30}$. This implies a $\delta^{15} \mathrm{~N}_{\text {N.p. }}$ value of $7 \pm 0.3 \%$ for complete consumption of AHW nitrate and $10 \pm 0.3 \%$ for complete consumption of PHW nitrate (errors are 1 s.d.; Methods). In the central Arctic, the coretop $\delta^{15} \mathrm{~N}_{\text {N.p. }}$ value of $6.1 \%$ at site B28 on the Lomonosov Ridge is lower than the value expected for complete consumption of AHW nitrate (blue line, Fig. $2)$, consistent with incomplete nitrate consumption in the central Arctic today ${ }^{17,23}$ (Fig. 1b). In the western Arctic, the coretop $\delta^{15} \mathrm{~N}_{\text {N.p. }}$ value of $8.3 \%$ at the southerly site B8 and $8.0 \%$ at the northerly site $\mathrm{B} 17$ are intermediate between the values expected for complete consumption of AHW and PHW nitrate (Fig. 2). Given complete western Arctic nitrate consumption today ${ }^{17,23}$ (Fig. 1b), we infer that these $\delta^{15} \mathrm{~N}_{\text {N.p. }}$ values indicate complete consumption of a mixture of PHW and AHW nitrate sources at the core sites. Mixing of AHW and PHW is probable at these sites on the Mendeleev Ridge, as they are overlain by the PHW-AHW boundary today ${ }^{18}$ (Fig. 2a). Moreover, mutidecadal shifts in PHW-AHW boundary position ${ }^{18,22}$ will change the influence of the PHW and AHW at these locations, and the coretop $\delta^{15} \mathrm{~N}_{\text {N.p. }}$ integrates over $\sim 1,000$ years.

The downcore $\delta^{15} \mathrm{~N}_{\text {N.p. }}$ shows three distinct intervals since 35,000 years ago (35 ka; Fig. 3a) corresponding to the late Holocene (5-0 ka), the early and middle Holocene (11-5 ka) and the last glacial period and deglaciation ( $35-11 \mathrm{ka}$ ) (see age models in Extended Data Fig. 3). During the last glacial period and deglaciation, the western Arctic $\delta^{15} \mathrm{~N}_{\text {N.p. }}$ values (5.9 $\pm 0.7 \%$ at B17; $5.1 \pm 0.6 \%$ at B8) were equal to or lower than the central Arctic $\delta^{15} \mathrm{~N}_{\text {N.p. }}(6.0 \pm 0.5 \%$ o at B28). At the end of the deglaciation, the $\delta^{15} \mathrm{~N}_{\text {N.p. }}$ increased significantly at all locations (statistical tests in Supplementary Table 1), but the western Arctic $\delta^{15} \mathrm{~N}_{\text {N.p. }}$ increase was around three times greater than in the central Arctic. During the Holocene, the western Arctic $\delta^{15} \mathrm{~N}_{\text {N.p. }}$ values of $7.7-8.7 \%$ o were around $1-3 \%$ o higher than the central Arctic $\delta^{15} \mathrm{~N}_{\text {N.p. }}$ values. Whereas there is no apparent Holocene trend in the western Arctic $\delta^{15} \mathrm{~N}_{\text {N.p. }}$, the central Arctic $\delta^{15} \mathrm{~N}_{\text {N.p. }}$ declined significantly after $5 \mathrm{ka}$ (Fig. $3 \mathrm{a}$ and Supplementary Table 1).

Following modern observations, we interpret past $\delta^{15} \mathrm{~N}_{N . p .}$ values to reflect changes in both nitrate sources and the completeness of nitrate consumption, with the latter modulated by the strength of salinity-driven density stratification.

\section{Past Arctic Ocean nitrate sources}

The expanded ice sheets of the last glacial period drove a lower global mean sea level ${ }^{31}$, exposing the Arctic shelves and the Bering Strait $^{32,33}$ (Fig. 3b). Under this configuration, Pacific waters could not flow into the Arctic, and the lower western Arctic $\delta^{15} \mathrm{~N}_{\text {N.p. }}$ value in part reflected the replacement of PHW nitrate with AHW nitrate.

The postglacial flooding of the Bering Strait has been dated to $13-11 \mathrm{ka}$, with complete inundation occurring after $11.5 \mathrm{ka}$ (refs. ${ }^{33,34}$ ) (Fig. 3b). Accordingly, the rapid increase in the western Arctic $\delta^{15} \mathrm{~N}_{\text {N.p. }}$ values at $\sim 11 \mathrm{ka}$ probably records the resumption of Pacific water inflow due to Bering Strait flooding. Furthermore, the highest Holocene western Arctic $\delta^{15} \mathrm{~N}_{\text {N.p. }}$ values occurred within 


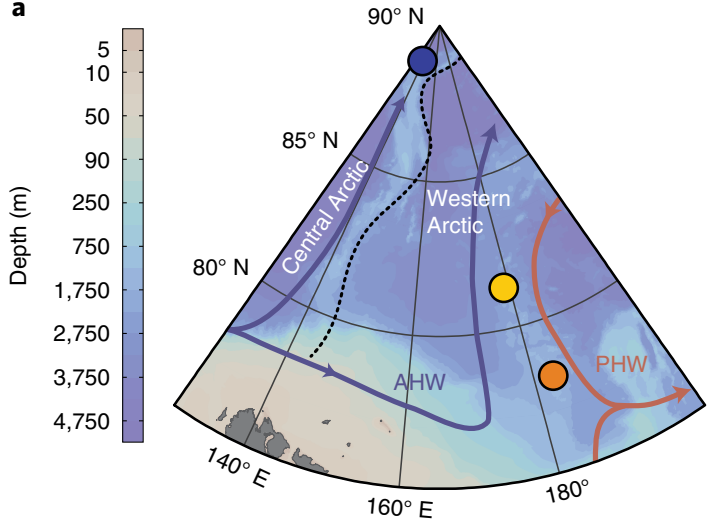

b

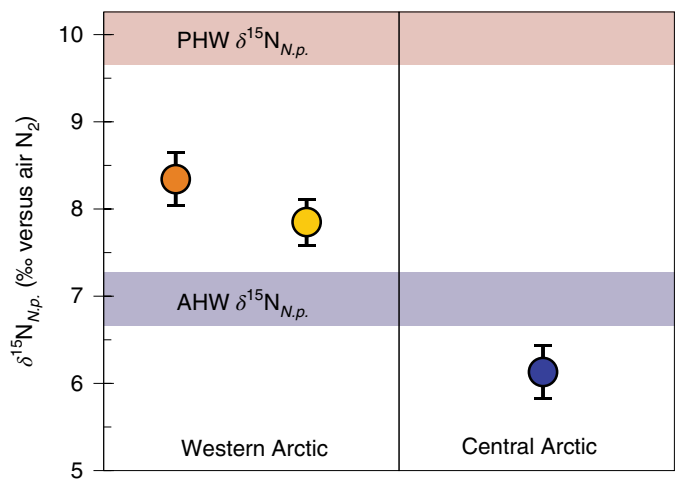

Fig. 2 | Arctic Ocean coretop $\boldsymbol{\delta}^{15} \mathbf{N}_{\text {N.p. }}$ a, Close-up bathymetric map of core locations, plotted using ODV ${ }^{51}$. The black dashed line denotes the boundary between the central and western Arctic Ocean along the Lomonosov Ridge. Blue and pale red lines trace the AHW and PHW pathways ${ }^{18}$ as in Fig. $1 a$. b, Horizontal blue and pale red bars indicate the expected $\delta^{15} \mathrm{~N}_{\text {N.p. }}$ from complete consumption of AHW and PHW nitrate, respectively, with the $\delta^{15} \mathrm{~N}_{\text {N.p. }}$ elevated by $2 \%$ above nitrate $\delta^{15} \mathrm{~N}$ (Methods). The intermediate western Arctic $\delta^{15} \mathrm{~N}_{\text {N.p. }}$ between AHW and PHW nitrate indicates complete consumption of a mixture of AHW and PHW nitrate at these locations. The central Arctic $\delta^{15} \mathrm{~N}_{\text {N.p. }}$ is lower than AHW nitrate $\delta^{15} \mathrm{~N}$, consistent with incomplete consumption of nitrate in the modern central Arctic surface.

around 1,000 years following flooding of the Bering Strait. This suggests that benthic nitrogen loss on the Bering, Chukchi and East Siberian sea shelves, which contributes to the high $\delta^{15} \mathrm{~N}$ of modern PHW nitrate ${ }^{26-29}$, resumed rapidly upon Bering Strait flooding and did not require full inundation of the Arctic shelves, which was not completed until around $5 \mathrm{ka}$ (ref. ${ }^{35}$ ).

The modern central Arctic is not notably influenced by PHW nitrate (Fig. 1c) and could not have been during the last ice age when the Bering Strait was exposed. Moreover, we assume that the $\delta^{15} \mathrm{~N}$ of AHW nitrate has not changed over the study period, as supported by records from the North Atlantic (Methods; Extended Data Fig. 4). Thus, the $\delta^{15} \mathrm{~N}_{\text {N.p. }}$ of the central Arctic site B28 was probably not substantially affected by source nitrate changes.

\section{Completeness of nitrate consumption}

In the case of nitrate supply from AHW, a $\delta^{15} \mathrm{~N}_{N . p .}$ value of less than $7 \%$ indicates incomplete nitrate consumption (Fig. 2). During the last ice age, when AHW nitrate was the only nitrate source to the Arctic Ocean, the $\delta^{15} \mathrm{~N}_{\text {N.p. }}$ of 5-6\%o at all sites (Fig. 3a) indicates incomplete consumption throughout the Arctic Ocean. During the deglaciation, complete nitrate consumption first commenced at sites $\mathrm{B} 17$ and $\mathrm{B} 28$ at around $13 \mathrm{ka}$, as indicated by $\delta^{15} \mathrm{~N}_{\text {N.p. }}$ values of approximately $7 \%$. This timing corresponds to a deglacial meltwater pulse from the Mackenzie River into the Arctic Ocean ${ }^{36,37}$ (Extended Data Fig. 2). The event was not captured at site B8. At site B8, complete nitrate consumption commenced by around $11 \mathrm{ka}$, coincident with flooding of the Bering Strait (Fig. 3).

Over the Holocene, the $\delta^{15} \mathrm{~N}_{\text {N.p. }}$ values at sites $\mathrm{B} 8$ and $\mathrm{B} 17$ suggest that complete nitrate consumption persisted in the western Arctic; we propose that the $\sim 1 \%$ variations in $\delta^{15} \mathrm{~N}_{\text {N.p. }}$ indicate changes in the relative proportions of PHW and AHW at these locations instead of consumption changes (Methods; Extended Data Fig. 5). In the central Arctic, $\delta^{15} \mathrm{~N}_{\text {N.p. }}$ at site B28 follows boreal summer insolation across the Holocene (Fig. $3 \mathrm{c}$ ). These data indicate that central Arctic nitrate consumption was complete in the early and middle Holocene during peak summer insolation but became incomplete after $5 \mathrm{ka}$ as the summer insolation decreased.

The reconstructed decline in the degree of nitrate consumption could represent reduced nitrate demand in the PML due to less favourable conditions for phytoplankton growth, or to greater nitrate supply to the PML due to weaker stratification. Today, incomplete nitrate consumption in the Eurasian Basin is attributed to light limitation of primary production by sea ice ${ }^{5}$, although grazing pressure ${ }^{20}$ or iron limitation ${ }^{38}$ may also contribute locally. However, none of these demand-based mechanisms appear to explain the past changes in nitrate consumption indicated by $\delta^{15} \mathrm{~N}_{\text {N.p. }}$ values. While the sea-ice extent was reduced in the Arctic marginal seas in the early and middle Holocene (Extended Data Fig. 2), central Arctic site B28 was probably perennially ice covered throughout the Holocene ${ }^{39}$, suggesting that higher early and middle Holocene nitrate consumption occurred without corresponding alleviation of light limitation. Moreover, the abrupt change from incomplete to complete nitrate consumption in the western Arctic at around $11 \mathrm{ka}$ occurs without an apparent change in sea-ice coverage $^{40}$, arguing against alleviation of light limitation as the cause of the increased nitrate consumption at that time. Thus, the changes in the degree of nitrate consumption are best attributed to changes in nitrate supply, as controlled by the density stratification of the Arctic upper water column $n^{23,24}$.

\section{Density stratification and freshwater input}

The changes in nitrate supply indicated by $\delta^{15} \mathrm{~N}_{\text {N.p. }}$ values require weaker stratification throughout the Arctic Ocean during the ice age and early deglaciation, pervasively stronger stratification in the early and middle Holocene, and a bifurcation in the late Holocene, with continued strong stratification in the western Arctic but weaker stratification in the central Arctic (Fig. 4). This stratification history can be explained by changes in freshwater input to the Arctic Ocean. In both simple conceptual ${ }^{41}$ and coupled ice-ocean models ${ }^{42}$, the strength of Arctic stratification scales with freshwater input, with greater freshwater input shoaling the PML and strengthening the halocline.

During the last glacial period and early deglaciation (Fig. 4c), freshwater input to the Arctic was reduced due to the closure of the Bering Strait, which today accounts for around $30 \%$ of total freshwater inflows to the Arctic Ocean ${ }^{10}$, alongside lower precipitation in the Arctic region under a colder regional climate and ice-damming of major Arctic rivers ${ }^{43}$. The $\delta^{15} \mathrm{~N}_{N . p .}$ data show that incomplete nitrate consumption characterized the upper Arctic Ocean, consistent with weaker stratification in model simulations with reduced freshwater input ${ }^{41,42}$. Thus, the halocline was probably weaker and the PML was probably deeper during the last glacial period than today, leading to a greater nitrate supply and light limitation of phytoplankton growth, analogous to (but more extreme than) the 


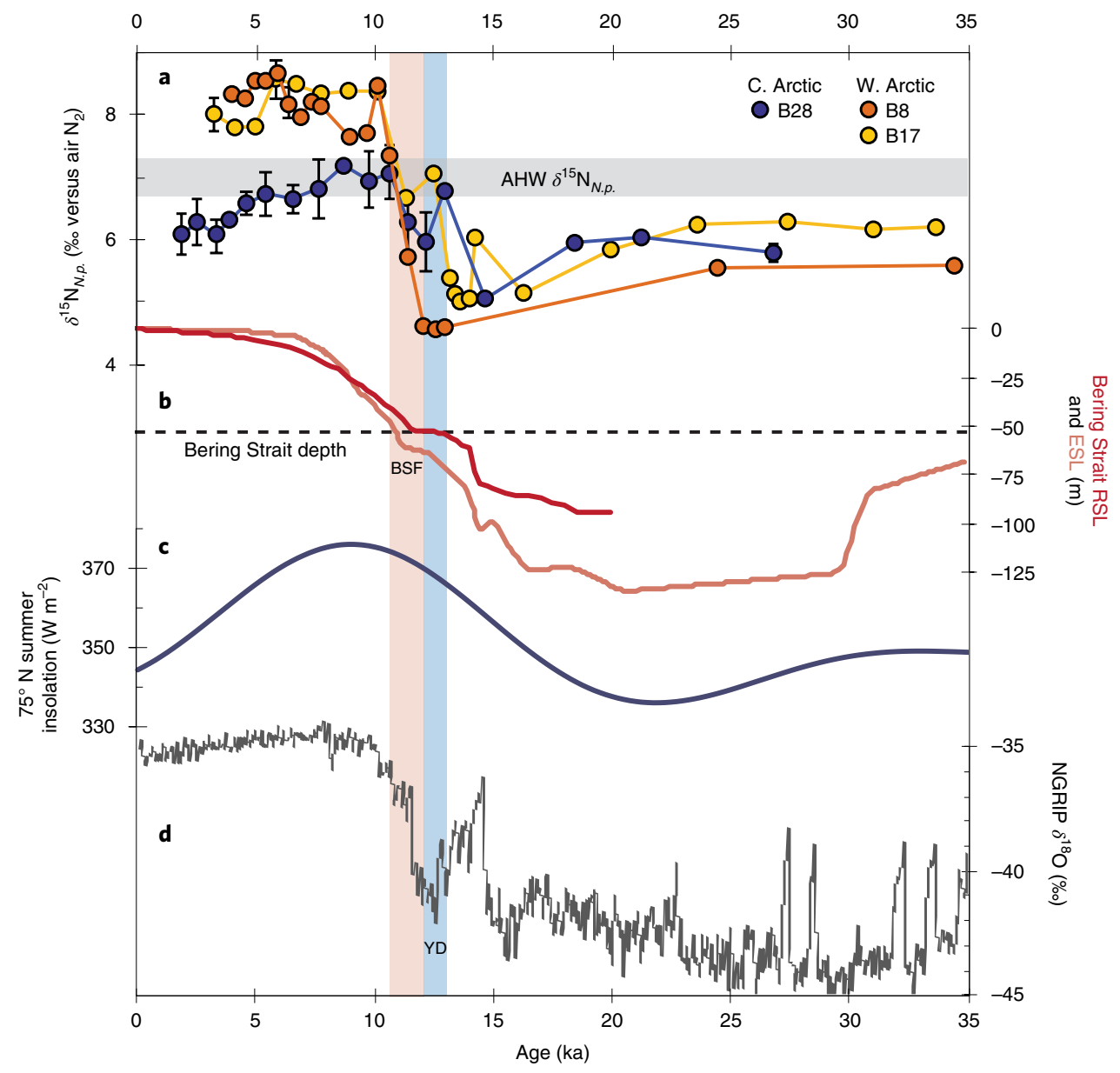

Fig. 3 | Arctic Ocean $\boldsymbol{\delta}^{15} \mathbf{N}_{\text {N.p. }}$ changes over the past 35,000 years and records related to their causes. a, Downcore $\delta^{15} \mathrm{~N}_{\text {N.p.; }}$ colours are as in Fig. 2. The horizontal grey bar is the expected $\delta^{15} \mathrm{~N}_{\text {N.p. }}$ from complete consumption of AHW nitrate. Error bars are $\pm 1 \mathrm{~s} . d$. from sample replicates (average $\pm 0.3 \%$, 1s.d.). b, Global ice volume equivalent sea level (ESL) ${ }^{31}$ (light red) and relative sea level (RSL) reconstructed at the Bering Strait ${ }^{33}$ (dark red). The horizontal dashed line indicates the modern depth of the Bering Strait. c, $75^{\circ} \mathrm{N}$ peak summer (21st June) insolation ${ }^{52}$. d, Ice $\delta^{18} \mathrm{O}$, a climate proxy, at the NGRIP ice core $^{45}$ (Fig. 1a). The vertical blue and red bars denote, respectively, the Younger Dryas (YD) event and the proposed timing of postglacial Bering Strait flooding (BSF) 33,34 .

Eurasian Basin today. This inference is supported by subsurface temperature reconstructions, which suggest a deeper halocline at the time ${ }^{44}$.

After $15 \mathrm{ka}$, our records indicate a sequence of deglacial events that enhanced freshwater inputs to, and stratification of, the Arctic Ocean. Oxygen isotopes in the NGRIP ice core ${ }^{45}$ (Fig. 3d) show that regional deglacial warming was punctuated by millennial-scale warming in the Bølling-Allerød period (14.7-12.9 ka) and cooling in the Younger Dryas period $(12.9-11.7 \mathrm{ka})$. Although riverine input to the Arctic Ocean increased during the Bølling-Allerød period $^{46}$, nitrate consumption remained incomplete throughout the Arctic at this time (Fig. 3a), suggesting that freshwater input was not yet sufficient to substantially intensify stratification. However, at $13 \mathrm{ka}$, meltwater discharge from the Mackenzie River ${ }^{36,37}$ appears to have strengthened Arctic Ocean stratification, explaining the more complete nitrate consumption at sites B17 and B28 (Fig. 3a and Extended Data Fig. 2). The lack of change at the most southerly site $\mathrm{B} 8$ may have been due to north and eastward routing of the meltwater ${ }^{36}$ (Fig. 1a). After $13 \mathrm{ka}$, the $\delta^{15} \mathrm{~N}_{N \text { p }}$ decline at site B28 (and possibly also at B17) suggests a brief return to weaker stratification, which may reflect the short duration $\left(\sim 700\right.$ years $\left.^{36}\right)$ of the meltwater event as well as lower rates of precipitation and riverine input ${ }^{46}$ during the cooler Younger Dryas period.
At $11 \mathrm{ka}, \delta^{15} \mathrm{~N}_{\text {N.p. }}$ of $\geq 7 \%$ o indicates complete nitrate consumption in both the western and central Arctic Ocean and hence strong stratification. The postglacial flooding of the Bering Strait at around 11 ka would have abruptly increased freshwater input to the western Arctic Ocean, leading to more intense stratification that, in turn, drove complete nitrate consumption. Together, the increase in nitrate consumption and coincident introduction of $\mathrm{PHW}$ nitrate to the western Arctic account for the large $\delta^{15} \mathrm{~N}_{\text {N.p. }}$ increase at sites B8 and B17 (Fig. 4b,c).

In the central Arctic Ocean, the $\delta^{15} \mathrm{~N}_{N, p}$ at site $\mathrm{B} 28$ also rose to $\sim 7 \%$ oround $11 \mathrm{ka}$. While this timing is coeval with the western Arctic $\delta^{15} \mathrm{~N}_{N . p .}$ increase and the postglacial flooding of the Bering Strait, the $\delta^{15} \mathrm{~N}_{\text {N.p. }}$ at site B28 has many other changes that are unrelated to the flooding of the Bering Strait. Moreover, PHW does not reach the central Arctic Ocean today, and the lack of $\delta^{15} \mathrm{~N}_{\text {N.p. }}$ measurements above $7 \%$ at site $\mathrm{B} 28$ suggests that PHW was absent from the central Arctic Ocean throughout our record (Fig. 4). Accordingly, we attribute the central Arctic $\delta^{15} \mathrm{~N}_{\text {N.p. }}$ rise at $11 \mathrm{ka}$ to stratification by other local freshwater sources, such as greater riverine input ${ }^{46}$ from ice sheet discharge and the breakup of ice-dammed Arctic rivers ${ }^{43}$. It is possible that the Bering Strait flooding played a role in triggering these additional freshwater sources to the central Arctic Ocean, explaining the coincidence of the $\delta^{15} \mathrm{~N}_{\text {N.p. }}$ rise at all sites. 
a

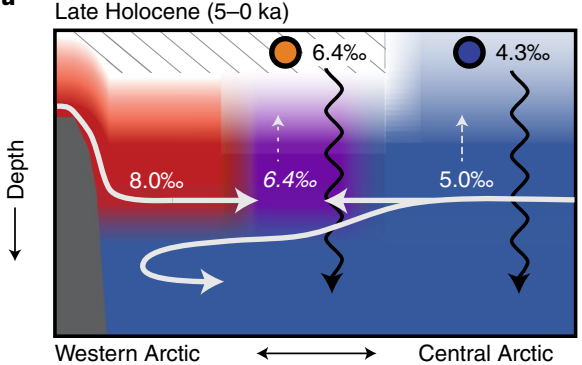

b

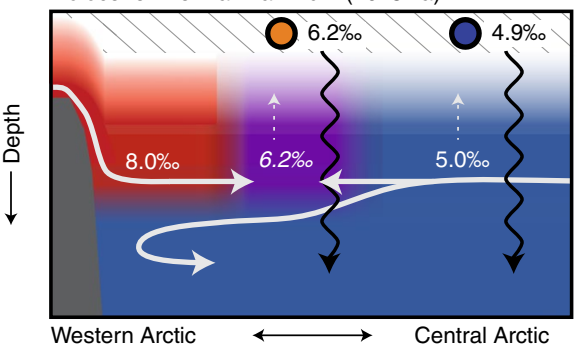

C Closed Bering Strait (35-11 ka)

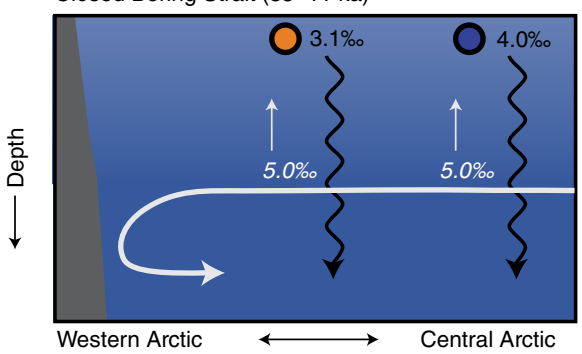

Nitrate source

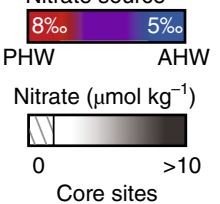

B8 828

Fig. 4 | Changes in Arctic Ocean nitrate sources and consumption since $35 \mathrm{ka}$. The colour indicates the nitrate source (blue is AHW, red is $\mathrm{PHW}$, purple is a mixture); the colour intensity indicates the nitrate concentration, with hatching indicating complete nitrate consumption and deeper shades representing higher nitrate concentrations. White lines and numbers indicate the transport of nitrate and its $\delta^{15} \mathrm{~N}$; black lines and numbers denote sinking organic matter and its $\delta^{15} \mathrm{~N}$. Italicized numbers are inferred on the basis of modern observations. For simplicity, only cores B8 and B28 are shown. a, Late Holocene (5-0 ka): PHW and complete nitrate consumption in the western Arctic, and $\mathrm{AHW}$ and incomplete nitrate consumption in the central Arctic. b. Holocene Thermal Maximum ${ }^{47-49}$ ( 10-5 ka): the same PHW/AHW configuration as a, but with complete nitrate consumption across the Arctic Ocean. c, Closed Bering Strait (before $11 \mathrm{ka}$ ): AHW only and incomplete nitrate consumption across the Arctic Ocean. Note that central Arctic changes between 13 and $11 \mathrm{ka}$ are not shown.

During the Holocene, the $\delta^{15} \mathrm{~N}_{\text {N.p. }}$ data indicate diverging nitrate consumption trajectories in the western and central Arctic Ocean. In the western Arctic, complete nitrate consumption and thus strong stratification persisted throughout the Holocene (Fig. 4a,b). We propose that this reflects robust stratification in the western Arctic maintained by the continuous input of low-salinity water across the Bering Strait.

In the central Arctic, complete nitrate consumption continued from 10 to $5 \mathrm{ka}$, indicating strong central Arctic Ocean stratification through the early and middle Holocene (Fig. 4b). This period, referred to as the Holocene Thermal Maximum (HTM), is characterized by a warmer-than-preindustrial summer climate in the

Arctic region and sea-ice retreat on the Arctic shelves ${ }^{39,46}$ due to high summer insolation ${ }^{47-49}$ (Extended Data Fig. 2). A strongly stratified central Arctic during the HTM suggests a sustained period of elevated freshwater input-riverine discharge ${ }^{46}$ and/or precipitationassociated with the warmer summers (Extended Data Fig. 2). After $5 \mathrm{ka}$, central Arctic Ocean $\delta^{15} \mathrm{~N}_{\text {N.p. }}$ declined in concert with summer insolation (Fig. $3 \mathrm{c}$ ), indicating that central Arctic Ocean stratification weakened in the late Holocene (Fig. 4a). This probably resulted from a decrease in the same freshwater sources that maintained the earlier stratification.

\section{Implications for the future Arctic Ocean}

The rapid increase in nitrate consumption during the reconnection of the North Pacific and Arctic oceans by 11 ka demonstrates that the high degree of nitrate consumption in the modern western Arctic Ocean, occurring despite extensive sea-ice cover, is largely a result of strong stratification. In turn, the development of strong stratification in the western Arctic Ocean by $11 \mathrm{ka}$ indicates that this stratification results from low-salinity inflow across the Bering Strait. In the central Arctic Ocean, greater nitrate consumption during the HTM indicates that stronger stratification characterized past warmer regional Arctic climates, which we suggest arose from greater freshwater input to the central Arctic Ocean in response to the warmer climate.

With regard to the future, climate models find that continued warming will lead to increased freshwater delivery to the Arctic Ocean $^{10}$ and enhanced stratification, with limited nutrient supply triggering oligotrophy ${ }^{6-8}$. By contrast, satellite-based estimates of Arctic Ocean productivity have increased during the past two decades ${ }^{3,50}$. An important caveat is that observed productivity increases have largely occurred on the Arctic shelves ${ }^{3,50}$ where Pacific and North Atlantic inflows and weaker stratification have enhanced the nutrient supply ${ }^{16,50}$. Our results provide insight into the factors controlling the nutrient supply to the extensive open Arctic Ocean, which is underrepresented in satellite-based estimates due to sea-ice cover ${ }^{3,50}$.

The HTM provides a useful point of comparison for future Arctic change ${ }^{39,49}$. A more strongly stratified central Arctic Ocean during the HTM (Fig. 4b) implies that stratification will probably increase as ongoing Arctic warming enhances freshwater input to the central Arctic Ocean ${ }^{10}$. Such stronger future central Arctic Ocean stratification would be a reversal from the recently observed weakening of stratification ${ }^{13,14}$ and a return to conditions most recently experienced during the HTM. This enhanced stratification will limit the nutrient supply even as sea-ice retreat alleviates light limitation. Thus, our reconstructions imply that future productivity in the central Arctic Ocean will become more strongly constrained by nutrient supply, as predicted by climate models ${ }^{6-8}$. This dynamic should reduce or prevent any productivity rise that might otherwise occur due to improved light availability with sea-ice loss.

In the western Arctic Ocean, the effect of global warming on water-column stratification may be less consequential. Global-warming-driven strengthening of the stratification would simply ensure that the western Arctic Ocean maintains the stratified, nutrient-limited conditions that have persisted since the flooding of the Bering Strait. In this sense, in the face of continued global warming, the open western basin will probably be the most biogeochemically stable region of the Arctic Ocean.

\section{Online content}

Any methods, additional references, Nature Research reporting summaries, source data, extended data, supplementary information, acknowledgements, peer review information; details of author contributions and competing interests; and statements of data and code availability are available at https://doi.org/10.1038/ s41561-021-00789-y. 
Received: 7 August 2020; Accepted: 3 June 2021;

Published online: 16 August 2021

\section{References}

1. Snow, Water, Ice and Permafrost in the Arctic (SWIPA) 2017 (Arctic Monitoring and Assessment Programme, 2017).

2. Meier, W. N. et al. Arctic sea ice in transformation: a review of recent observed changes and impacts on biology and human activity. Rev. Geophys. 52, 185-217 (2014).

3. Arrigo, K. R. \& van Dijken, G. L. Continued increases in Arctic Ocean primary production. Prog. Oceanogr. 136, 60-70 (2015)

4. SIMIP Community, Arctic sea ice in CMIP6. Geophys. Res. Lett. 47, e2019GL086749 (2020).

5. Tremblay, J.-É. et al. Global and regional drivers of nutrient supply, primary production and $\mathrm{CO}_{2}$ drawdown in the changing Arctic Ocean. Prog Oceanogr. 139, 171-196 (2015)

6. Vancoppenolle, M. et al. Future Arctic Ocean primary productivity from CMIP5 simulations: uncertain outcome, but consistent mechanisms. Global Biogeochem. Cycles 27, 605-619 (2013).

7. Slagstad, D., Wassmann, P. F. J. \& Ellingsen, I. Physical constrains and productivity in the future Arctic Ocean. Front. Mar. Sci. 2, 85 (2015).

8. Fu, W., Keith Moore, J., Primeau, F. W., Lindsay, K. \& Randerson, J. T. A growing freshwater lens in the Arctic Ocean with sustained climate warming disrupts marine ecosystem function. J. Geophys. Res. Biogeosci. 125, e2020JG005693 (2020).

9. Aagaard, K., Coachman, L. \& Carmack, E. On the halocline of the Arctic Ocean. Deep Sea Res. A 28, 529-545 (1981).

10. Haine, T. W. N. et al. Arctic freshwater export: status, mechanisms, and prospects. Global Planet. Change 125, 13-35 (2015).

11. Carmack, E. C. et al. Freshwater and its role in the Arctic marine system: sources, disposition, storage, export, and physical and biogeochemical consequences in the Arctic and global oceans. J. Geophys. Res. Biogeosci. 121, 675-717 (2016).

12. Woodgate, R. A. Increases in the Pacific inflow to the Arctic from 1990 to 2015 , and insights into seasonal trends and driving mechanisms from year-round Bering Strait mooring data. Prog. Oceanogr. 160, 124-154 (2018).

13. Polyakov, I. V. et al. Greater role for Atlantic inflows on sea-ice loss in the Eurasian Basin of the Arctic Ocean. Science 356, 285-291 (2017).

14. Polyakov, I. V., Pnyushkov, A. V. \& Carmack, E. C. Stability of the arctic halocline: a new indicator of arctic climate change. Environ. Res. Lett. 13, 125008 (2018).

15. Metzner, E. P., Salzmann, M. \& Gerdes, R. Arctic Ocean surface energy flux and the cold halocline in future climate projections. J. Geophys. Res. Oceans 125, e2019JC015554 (2020).

16. Polyakov, I. V. et al. Borealization of the Arctic Ocean in response to anomalous advection from sub-Arctic seas. Front. Mar. Sci. 7, 491 (2020).

17. Codispoti, L. et al. Synthesis of primary production in the Arctic Ocean: III Nitrate and phosphate based estimates of net community production. Prog. Oceanogr. 110, 126-150 (2013).

18. McLaughlin, F., Carmack, E., Macdonald, R., Weaver, A. J. \& Smith, J. The Canada Basin, 1989-1995: upstream events and far-field effects of the Barents Sea. J. Geophys. Res. 107, 3082 (2002).

19. Swift, J. et al. Waters of the Makarov and Canada basins. Deep Sea Res. 244 , 1503-1529 (1997)

20. Bluhm, B., Kosobokova, K. \& Carmack, E. A tale of two basins: an integrated physical and biological perspective of the deep Arctic Ocean. Prog. Oceanogr. 139, 89-121 (2015).

21. Woodgate, R. A., Aagaard, K. \& Weingartner, T. J. A year in the physical oceanography of the Chukchi Sea: moored measurements from autumn 1990-1991. Deep-Sea Res. Pt. II 52, 3116-3149 (2005).

22. Morison, J. et al. Changing Arctic Ocean freshwater pathways. Nature 481, 66-70 (2012).

23. Randelhoff, A. et al. Pan-Arctic Ocean primary production constrained by turbulent nitrate fluxes. Front. Mar. Sci. 7, 150 (2020).

24. Peralta-Ferriz, C. \& Woodgate, R. A. Seasonal and interannual variability of pan-Arctic surface mixed layer properties from 1979 to 2012 from hydrographic data, and the dominance of stratification for multiyear mixed layer depth shoaling. Prog. Oceanogr. 134, 19-53 (2015).

25. Van Oostende, N. et al. Variation of summer phytoplankton community composition and its relationship to nitrate and regenerated nitrogen assimilation across the North Atlantic Ocean. Deep Sea Res. 1 121, 79-94 (2017).

26. Fripiat, F. et al. Influence of the bordering shelves on nutrient distribution in the Arctic halocline inferred from water column nitrate isotopes. Limnol. Oceanogr. 63, 2154-2170 (2018).

27. Granger, J. et al. Coupled nitrification-denitrification in sediment of the eastern Bering Sea shelf leads to ${ }^{15} \mathrm{~N}$ enrichment of fixed $\mathrm{N}$ in shelf waters. J. Geophys. Res. Oceans 116, C11006 (2011).
28. Granger, J., Sigman, D. M., Gagnon, J. G., Tremblay, J.-E. \& Mucci, A. On the properties of the Arctic halocline and deep water masses of the Canada Basin from nitrate isotope ratios. J. Geophys. Res. Oceans 123, 5443-5458 (2018).

29. Brown, Z. W., Casciotti, K. L., Pickart, R. S., Swift, J. H. \& Arrigo, K. R. Aspects of the marine nitrogen cycle of the Chukchi Sea shelf and Canada Basin. Deep Sea Res. 2 118, 73-87 (2015).

30. Straub, M. et al. Nutrient conditions in the subpolar North Atlantic during the last glacial period reconstructed from foraminifera-bound nitrogen isotopes. Paleoceanography 28, 79-90 (2013).

31. Lambeck, K., Rouby, H., Purcell, A., Sun, Y. \& Sambridge, M. Sea level and global ice volumes from the Last Glacial Maximum to the Holocene. Proc. Natl Acad. Sci. USA 111, 15296-15303 (2014).

32. Jakobsson, M. et al. Arctic Ocean glacial history. Quat. Sci. Rev. 92, 40-67 (2014).

33. Pico, T., Mitrovica, J. X. \& Mix, A. C. Sea level fingerprinting of the Bering Strait flooding history detects the source of the Younger Dryas climate event. Sci. Adv. 6, eaay2935 (2020).

34. Jakobsson, M. et al. Post-glacial flooding of the Bering Land Bridge dated to $11 \mathrm{calka}$ BP based on new geophysical and sediment records. Clim. Past 13, 991-1005 (2017).

35. Bauch, H. A. et al. Chronology of the Holocene transgression at the North Siberian margin. Global Planet. Change 31, 125-139 (2001).

36. Keigwin, L. D. et al. Deglacial floods in the Beaufort Sea preceded Younger Dryas cooling. Nat. Geosci. 11, 599-604 (2018).

37. Tarasov, L. \& Peltier, W. R. Arctic freshwater forcing of the Younger Dryas cold reversal. Nature 435, 662-665 (2005).

38. Rijkenberg, M. J. A., Slagter, H. A., van der Loeff, M. R., van Ooijen, J. \& Gerringa, L. J. A. Dissolved Fe in the deep and upper Arctic Ocean with a focus on Fe limitation in the Nansen Basin. Front. Mar. Sci. 5, 88 (2018).

39. de Vernal, A. et al. Natural variability of the Arctic Ocean sea ice during the present interglacial. Proc. Natl Acad. Sci. USA 117, 26069-26075 (2020).

40. de Vernal, A., Hillaire-Marcel, C. \& Darby, D. A. Variability of sea ice cover in the Chukchi Sea (western Arctic Ocean) during the Holocene. Paleoceanography 20, PA4018 (2005).

41. Nilsson, J. \& Walin, G. Salinity-dominated thermohaline circulation in sill basins: can two stable equilibria exist? Tellus A 62, 123-133 (2010).

42. Pemberton, P. \& Nilsson, J. The response of the central Arctic Ocean stratification to freshwater perturbations. J. Geophys. Res. Oceans 121, 792-817 (2016)

43. Polyak, L., Niessen, F., Gataullin, V. \& Gainanov, V. The eastern extent of the Barents-Kara ice sheet during the Last Glacial Maximum based on seismicreflection data from the eastern Kara Sea. Polar Res. 27, 162-172 (2008).

44. Cronin, T. M. et al. Deep Arctic Ocean warming during the last glacial cycle. Nat. Geosci. 5, 631-634 (2012).

45. North Greenland Ice Core Project members, High-resolution record of Northern Hemisphere climate extending into the last interglacial period. Nature 431, 147-151 (2004).

46. Hörner, T., Stein, R., Fahl, K. \& Birgel, D. Post-glacial variability of sea ice cover, river run-off and biological production in the western Laptev Sea (Arctic Ocean) - a high-resolution biomarker study. Quat. Sci. Rev. 143, 133-149 (2016)

47. Kaufman, D. S. et al. Holocene thermal maximum in the western Arctic (0-180 W). Quat. Sci. Rev. 23, 529-560 (2004).

48. Park, H.-S., Kim, S.-J., Stewart, A. L., Son, S.-W. \& Seo, K.-Y. Mid-Holocene Northern Hemisphere warming driven by Arctic amplification. Sci. Adv. 5, eaax8203 (2019)

49. Axford, Y., de Vernal, A. \& Osterberg, E. C. Past warmth and its impacts during the holocene thermal maximum in greenland. Annu. Rev. Earth. Planet. Sci. 49, 279-307 (2021)

50. Lewis, K. M., van Dijken, G. L. \& Arrigo, K. R. Changes in phytoplankton concentration now drive increased Arctic Ocean primary production. Science 369, 198-202 (2020).

51. Schlitzer, R. Ocean Data View (ODV Forum, 2021); http://odv.awi.de

52. Laskar, J. et al. A long-term numerical solution for the insolation quantities of the Earth. Astron. Astrophys. 428, 261-285 (2004).

Publisher's note Springer Nature remains neutral with regard to jurisdictional claims in published maps and institutional affiliations.

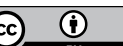

Open Access This article is licensed under a Creative Commons Attribution 4.0 International License, which permits use, sharing, adaptation, distribution and reproduction in any medium or format, as long as you give appropriate credit to the original author(s) and the source, provide a link to the Creative Commons license, and indicate if changes were made. The images or other third party material in this article are included in the article's Creative Commons license, unless indicated otherwise in a credit line to the material. If material is not included in the article's Creative Commons license and your intended use is not permitted by statutory regulation or exceeds the permitted use, you will need to obtain permission directly from the copyright holder. To view a copy of this license, visit http://creativecommons.org/licenses/by/4.0/.

(c) The Author(s) 2021 


\section{Methods}

Sediment cores and chronology. The 1994 Arctic Ocean Section (or AOS94) collected Mark III box cores $(40 \times 40 \times 60 \mathrm{~cm})$ along a transect from the Mendeleev Ridge to the Lomonosov Ridge ${ }^{53}$. Each box core was subsampled with $10 \mathrm{~cm}$ diameter plastic tubes. Our samples are sourced from the 'B' tube at site B8 $\left(78.13^{\circ} \mathrm{N}, 176.74^{\circ} \mathrm{W}, 1,031 \mathrm{~m}\right.$ water depth $)$ and site $\mathrm{B} 17\left(81.27^{\circ} \mathrm{N}, 178.97^{\circ} \mathrm{E}\right.$ $2,217 \mathrm{~m}$ water depth) from the Mendeleev Ridge, and at site B28 $\left(88.87^{\circ} \mathrm{N}\right.$, $140.18^{\circ} \mathrm{E}, 1,990 \mathrm{~m}$ water depth) from the Lomonosov Ridge. Sediment samples were taken every $1 \mathrm{~cm}$. Approximately 1,500 N. pachyderma sinistral (Ehrenberg) tests $(\sim 5-7 \mathrm{mg})$ were picked from the $212-300 \mu \mathrm{m}$ size fraction using a binocular microscope.

Age models were created from existing ${ }^{14} \mathrm{C}$ dates on N. pachyderma from B8, B17 and B28 (refs. ${ }^{53-55}$ ). All existing dates were recalibrated using Marine20 (ref. ${ }^{56}$ ) and no local reservoir correction was applied (that is, $\Delta R=0$ years). This choice of calibration scheme reflects several considerations:

1. While high-latitude oceans have sluggish air-sea ${ }^{14} \mathrm{C}$ equilibration due to upwelling and/or sea-ice coverage, the upper Arctic Ocean is primarily ventilated along horizontal (advective) pathways and not local vertical mixing. The extremely old marine reservoir ages for the Arctic Ocean ( $>1,500$ years) suggested by coarse-resolution ocean-circulation models ${ }^{57}$ are not consistent with the prevalence of well-ventilated Atlantic water inflow to the Arctic over the timespan of this study ${ }^{36,44}$, probably because such simulations do not capture these advective ventilation pathways.

2. Higher prebomb marine reservoir ages (of $\sim 500$ years) observed in near-shore western Arctic waters reflect the input of older Pacific-sourced waters transiting across the Bering Strait. Thus, there is an expectation that Arctic marine reservoir ages may have been younger when the Bering Strait was exposed ${ }^{36}$, in contrast with previous expectations for older marine reservoir ages at this time ${ }^{58}$

3. We conservatively choose not to assume a particular $\Delta R$ history given the few available constraints of past Arctic marine reservoir ages. Instead, we allow that our calculated ages may be imprecise due to past changes in $\Delta R$ and interpret our data on millennial or longer timescales.

Age models (Extended Data Fig. 3) were created using Bayesian age-depth modelling of calibrated calendar ages in 'Bacon'59 using an accumulation rate prior of $500 \mathrm{yr} \mathrm{cm}^{-1}$, an accumulation shape prior of 1.5, a default section thickness of $5 \mathrm{~cm}$ and default autocorrelation priors of memory strength 4 and memory mean 0.7. For B28, all available ${ }^{14} \mathrm{C}$ dates (number of samples, $N=15$ ) from ref. ${ }^{53}$ were incorporated into the age-depth model. For B8 and B17, combining ${ }^{14} \mathrm{C}$ datasets from different studies resulted in poor mixing of the Markov Chain Monte Carlo age-depth iterations, as indicated by a Gelman and Rubin reduction factor ${ }^{60}$ of $>1.05$. This was addressed by using only ${ }^{14} \mathrm{C}$ dates from ref. ${ }^{54}$ in our age-depth models for B8 and B17. Disagreement between ${ }^{14} \mathrm{C}$ ages is most pronounced for dates before $20 \mathrm{ka}$ and may reflect that dates were obtained from different subsampled 'push cores' with 1-2 cm misalignments in the sample depths ${ }^{53}$. Nonetheless, our resulting age models show coherent Arctic Ocean sedimentation-rate patterns, with higher sedimentation rates of $0.5-2 \mathrm{~cm}$ per kyr during the Holocene and late Marine Isotope Stage 3, and lower sedimentation rates of $0.2-0.4 \mathrm{~cm}$ per kyr during Marine Isotope Stage 2, as observed previously $\mathrm{y}^{44,53,55,61}$. Note that the higher sedimentation-rate uncertainty before $15 \mathrm{ka}$ reflects the few available ${ }^{14} \mathrm{C}$ dates and the low sedimentation rates during peak glacial conditions ${ }^{55}$. This uncertainty does not materially affect our interpretations as we do not interpret millennial-scale patterns before $15 \mathrm{ka}$.

Seawater nitrate isotope analyses. Seawater samples for nitrate isotope analyses were collected along the western Arctic Ocean GEOTRACES transect (ARC01). Collected samples were filtered through a $0.2 \mu \mathrm{m}$ polyethersulfone membrane into pre-rinsed $60 \mathrm{ml}$ high-density polyethylene bottles and were stored frozen until analysis. Nitrite was removed by sulfamic acid addition ${ }^{62}$ before analysis in samples in which nitrite was detected. Twenty nanomoles of nitrate were reduced to $\mathrm{N}_{2} \mathrm{O}$ gas via the denitrifier method ${ }^{63}$. Nitrogen and oxygen isotopes were measured on the $\mathrm{N}_{2} \mathrm{O}$ by continuous-flow isotope ratio mass spectrometry using a Thermo Delta $\mathrm{V}$ Advantage spectrometer with a purpose-built, gas chromatography-based device for $\mathrm{N}_{2} \mathrm{O}$ extraction, concentration and purification ${ }^{64,65}$ at the University of Connecticut. Samples were analysed in duplicate, yielding an average $\delta^{15} \mathrm{~N}$ standard deviation of $0.2 \%$.

Foraminifera-bound nitrogen isotope analyses. N. pachyderma samples were gently crushed between glass slides and subjected to clay removal, reduction with buffered sodium dithionite to remove the oxide coatings, and oxidation with buffered potassium persulfate to remove non-bound organic material, following standard protocols ${ }^{66,67}$. Cleaned foraminiferal carbonate was dissolved in $4 \mathrm{M}$ $\mathrm{HCl}$ to release the bound organic nitrogen, which was then oxidized to nitrate using basic potassium persulfate ${ }^{66-68}$. Nitrate was converted to $\mathrm{N}_{2} \mathrm{O}$ gas via the denitrifier method ${ }^{63}$, and the $\delta^{15} \mathrm{~N}$ of the $\mathrm{N}_{2} \mathrm{O}$ was measured using a purpose-built, automated, helium continuous-flow-based extraction and purification system at Princeton University ${ }^{69}$. Analytical precision based on long-term replication internal carbonate-bound organic $\mathrm{N}$ standards is $\leq \pm 0.30 \%$ ( 1 s.d.). The reported analytical precision is 1 s.d. for duplicate $\delta^{15} \mathrm{~N}$ analyses on sample splits that underwent separate cleaning, oxidation and bacterial conversion to $\mathrm{N}_{2} \mathrm{O}$, and averaged $\pm 0.31 \%$ o (1 s.d., $N=18$ ).

Comparison of $N$. pachyderma $\delta^{15} \mathrm{~N}$ with bulk-sediment $\delta^{15} \mathrm{~N}$. Bulk-sediment $\delta^{15} \mathrm{~N}$ is vulnerable to diagenetic alteration and contamination by allochthonous organic matter (for example, ref. ${ }^{70}$ ). These vulnerabilities encouraged the development of the $\delta^{15} \mathrm{~N}$ of foraminifera-bound organic matter as a palaeoceanographic proxy. The organic matter in foraminifera tests is purely marine in origin (deriving from the host organism) and is protected from diagenetic alteration by the calcite test ${ }^{71}$. Alteration and contamination of bulk-sediment $\delta^{15} \mathrm{~N}$ are pronounced in the Arctic Ocean ${ }^{72}$, as further demonstrated by comparing $\delta^{15} \mathrm{~N}_{N, p}$ with bulk-sediment $\delta^{15} \mathrm{~N}$. Lacking matching bulk-sediment and foraminifera-bound $\delta^{15} \mathrm{~N}$ data from the same core, we compare the $\delta^{15} \mathrm{~N}_{N . p}$ values from central Arctic Ocean site B28 with a bulk-sediment $\delta^{15} \mathrm{~N}$ record at site PS2185-4 $\left(87.5^{\circ} \mathrm{N}, 144.5^{\circ} \mathrm{E}\right)$, which is also located on the Lomonosov Ridge approximately $150 \mathrm{~km}$ to the south of site B28 ${ }^{73}$. An age model for PS2185-4 was constructed from 15 accelerator mass spectrometry ${ }^{14} \mathrm{C}$ dates on $N$. pachyderma ${ }^{7}$ using the above parameters (see 'Sediment cores and chronology'). Both sites are $>800 \mathrm{~km}$ from the nearest shelf area and should record comparable open central Arctic Ocean conditions.

Extended Data Fig. 1 shows that, while site $\delta^{15} \mathrm{~N}_{\text {N.p. }}$ data from site $\mathrm{B} 28$ and PS2185-4 bulk sediment $\delta^{15} \mathrm{~N}$ data have similar values in the late Holocene and both increase between the last glacial period and the late Holocene, the two records otherwise have a very different structure. The differences may be explained by changes in the ratio of terrigenous to marine organic $\mathrm{N}$ in the sediment, which biases bulk sediment $\delta^{15} \mathrm{~N}$ but does not affect $\delta^{15} \mathrm{~N}_{\text {N.p. }}$. Terrigenous organic material typically has a low $\delta^{15} \mathrm{~N}$, as do Mackenzie River sediments $\left(1.4-2.8 \%\right.$ o, ref. ${ }^{75}$ ) and riverine dissolved organic nitrogen along the Laptev Sea shelf $\left(2.1 \%\right.$, ref. $\left.{ }^{76}\right)$. Thus, lower values of bulk sediment $\delta^{15} \mathrm{~N}$ compared with $\delta^{15} \mathrm{~N}_{\text {N.p. }}$ before $5 \mathrm{ka}$ may reflect a greater proportion of terrigenous nitrogen relative to marine organic nitrogen in the sediment (see ref. ${ }^{73}$ ).

Reconstructing nutrient consumption from $\delta^{15} \mathbf{N}_{\text {N.p. }}$. Phytoplankton preferentially assimilate ${ }^{14} \mathrm{~N}$-bearing nitrate, leaving the residual nitrate pool enriched in ${ }^{15} \mathrm{~N}$ (ref. ${ }^{77,78}$ ). As heterotrophic zooplankton, foraminifera consume (and source their nitrogen from) phytoplankton. Consequently, the $\delta^{15} \mathrm{~N}$ of phytoplankton biomass consumed by foraminifera decreases with lower degrees of nitrate consumption and increases as consumption increases to completeness. With seasonally complete nitrate consumption, the $\delta^{15} \mathrm{~N}$ of integrated net biomass production must equal the $\delta^{15} \mathrm{~N}$ of the underlying nitrate supply, that is, the $\delta^{15} \mathrm{~N}$ of AHW or PHW nitrate.

The $\delta^{15} \mathrm{~N}$ of biomass produced from a given nitrate source can be simulated with the Rayleigh model, which assumes that nitrate consumption occurs in a closed system with constant isotopic fractionation ${ }^{79-81}$. Over the course of the growing season, the accumulated biomass $\delta^{15} \mathrm{~N}$ is given by

$$
\delta^{15} \mathrm{~N}_{\text {accumulated }}=\delta^{15} \mathrm{~N}_{\text {nitrate }}+\epsilon_{\text {assimilation }} \times[f /(1-f)] \times \ln f
$$

where $\delta^{15} \mathrm{~N}_{\text {nitrate }}$ is the $\delta^{15} \mathrm{~N}$ of the reactant nitrate source, $f$ is the degree of seasonal nitrate consumption given by the concentration ratio between the remaining nitrate and the nitrate supply, and $\varepsilon_{\text {assimilation }}$ is the isotope effect of nitrate assimilation, which is set to $5 \%$ given available constraints ${ }^{81,82}$

The $\delta^{15} \mathrm{~N}$ of organic matter preserved in $N$. pachyderma $\left(\delta^{15} \mathrm{~N}_{\text {N.p. }}\right.$ as in the main text) is observed to be $\sim 2 \%$ elevated over $\delta^{15} \mathrm{~N}_{\text {accumulated }}$ in the North Atlantic ${ }^{30}$, a region of complete nitrate consumption today (where $f \sim 0$, so equation (1) simplifies to $\delta^{15} \mathrm{~N}_{\text {accumulated }}=\delta^{15} \mathrm{~N}_{\text {nitrate }}$. The ${ }^{15} \mathrm{~N}$ enrichment in non-spinose, symbiont-barren $N$. pachyderma is consistent with $\delta^{15} \mathrm{~N}$ elevation observed in non-spinose, symbiont-barren foraminifera over thermocline nitrate $\delta^{15} \mathrm{~N}$ in oligotrophic subtropical gyres with complete nitrate consumption ${ }^{83,84}$. Given that $N$. pachyderma shows a strong seasonal flux bias to peak summer at high latitudes ${ }^{85}$, we assume that the diet of $N$. pachyderma reflects the biomass accumulated throughout the growing season ${ }^{30}$. This allows for calculating the degree of nitrate consumption $(f)$ from $\delta^{15} \mathrm{~N}_{N . p .}$ using the Rayleigh accumulated product model (equation (1))

$$
\left(\delta^{15} \mathrm{~N}_{N . p .}-2\right)=\delta^{15} \mathrm{~N}_{\text {nitrate }}+5 \times[f /(1-f)] \times \ln f
$$

where $\delta^{15} \mathrm{~N}_{\text {nitrate }}$ is $5 \%$ o for AHW (Fig. 1c). This calculation is more challenging in the case of mixed AHW and PHW sources, a situation that only occurs after $11 \mathrm{ka}$ in the western Arctic Ocean. For this period, we assume complete nitrate consumption $(f \approx 0)$ and that $\delta^{15} \mathrm{~N}_{\text {N.p. }}$ variations reflect the changing proportions of AHW and $\mathrm{PHW}$ at this location, as supported by palaeoceanographic data (see below).

Stability of AHW $\boldsymbol{\delta}^{15} \mathbf{N}_{\text {nitrate }}$ since $35 \mathrm{ka}$. We assume that AHW nitrate has maintained a constant $\delta^{15} \mathrm{~N}$ value of $5 \%$ over the past $35 \mathrm{ka}$ (for example, Fig. 3a) based on several lines of evidence. Today, the $\delta^{15} \mathrm{~N}$ of AHW nitrate is a function of the contributing water masses to high-latitude North Atlantic subsurface waters plus any isotopic imprint from local $\mathrm{N}_{2}$ fixation or water-column denitrification; the latter two are negligible for AHW given the absence of these processes in cold, well-oxygenated high-latitude North Atlantic waters ${ }^{25,26,86}$. Instead, the 
$\delta^{15} \mathrm{~N}$ of AHW nitrate is primarily inherited from water masses that contribute to high-latitude North Atlantic subsurface waters. These include subtropical North Atlantic central waters (NACW), with low $\delta^{15} \mathrm{~N}_{\text {nitrate }}$ from regional $\mathrm{N}_{2}$ fixation ${ }^{87}$, and Southern Ocean mode water (SAMW) and Antarctic intermediate water, which have higher nitrate $\delta^{15} \mathrm{~N}$ due to partial nitrate consumption in the surface Southern Ocean $^{86}$. The resultant mixture of these source water masses imparts high-latitude North Atlantic subsurface waters and ultimately AHW with a $\delta^{15} \mathrm{~N}_{\text {nitrate }}$ of $\sim 5 \%$, which is approximately equal to the mean deep ocean nitrate $\delta^{15} \mathrm{~N}$ (refs. ${ }^{25,86}$ ).

Past changes in AHW nitrate $\delta^{15} \mathrm{~N}$ could result from changing contributions of, or the $\delta^{15} \mathrm{~N}$ of nitrate in, these source water masses. Foraminifera-bound $\delta^{15} \mathrm{~N}$ records from the Atlantic basin inform us as to the nitrate $\delta^{15} \mathrm{~N}$ of these water masses in the past (Extended Data Fig. 4a,b). Foraminifera-bound $\delta^{15} \mathrm{~N}$ from the subtropical North Atlantic is elevated before $11 \mathrm{ka}$ (refs. ${ }^{71,88}$ ), indicating reduced regional $\mathrm{N}_{2}$ fixation and thus a higher $\delta^{15} \mathrm{~N}_{\text {nitrate }}$ of NACW (Extended Data Fig. 4a). In isolation, higher $\delta^{15} \mathrm{~N}_{\text {nitrate }}$ in NACW would tend to increase the AHW nitrate $\delta^{15} \mathrm{~N}$ before $11 \mathrm{ka}$, the opposite sense of change that would explain our results. With regard to Southern Ocean contributions, nitrate consumption was more complete within the Southern Ocean source regions of mode and intermediate waters before 11 ka (ref. ${ }^{89}$ ) (Extended Data Fig. 4b). However, high degrees of consumption in the Southern Ocean would have meant that any high- $\delta^{15} \mathrm{~N}$ residual nitrate that was input into the SAMW was at a lower nitrate concentration. As a consequence, this nitrate $\delta^{15} \mathrm{~N}$ in Southern Ocean-sourced thermocline waters would have been quickly moderated downwards by mixing with underlying nitrate-rich deep water, with its nitrate $\delta^{15} \mathrm{~N}$ of $\sim 5 \%$ (ref. ${ }^{89}$ ). Thus, the reconstructed Southern Ocean nutrient consumption changes probably had a limited capacity to change nitrate $\delta^{15} \mathrm{~N}$ in SAMW or downstream in AHW.

Although direct reconstructions of past AHW $\delta^{15} \mathrm{~N}_{\text {nitrate }}$ are not currently possible given the confounding influence of changing nitrate consumption (for example, equation (2)), proximal data suggest relatively constant nitrate $\delta^{15} \mathrm{~N}$ in the high latitude North Atlantic source region of AHW (Extended Data Fig. 4c,d). A $\delta^{15} \mathrm{~N}_{\text {N.p. }}$. record from $57^{\circ} \mathrm{N}$ shows values of $\sim 7 \%$ o during the Holocene that decline to around $4-6 \%$ o during the last glacial period ${ }^{30}$ (Extended Data Fig. $4 \mathrm{c}$ ). These declines are interpreted to represent incomplete nitrate consumption in the subpolar North Atlantic Ocean. Two exceptions are $\delta^{15} \mathrm{~N}_{\text {N.p. }}$ values of $\sim 7 \%$ o during Heinrich Events 2 and 3 , which are argued to reflect intervals of complete surface nitrate consumption due to strong stratification ${ }^{30}$. Given the $2 \%$ o elevation of $\delta^{15} \mathrm{~N}_{N . p}$ over nitrate $\delta^{15} \mathrm{~N}$, these results from intervals of putatively complete consumption (the Holocene and Heinrich events) imply a generally constant $\delta^{15} \mathrm{~N}_{\text {nitrate }}$ of around $5 \%$ in the North Atlantic Ocean upstream of the Arctic Ocean. Additionally, a foraminifera-bound $\delta^{15} \mathrm{~N}$ record from the oligotrophic subtropical North Atlantic Ocean $\left(31^{\circ} \mathrm{N}\right)$ suggests a nitrate $\delta^{15} \mathrm{~N}$ of $5-5.5 \%$ during the last glacial period ${ }^{90}$. Northward transport of this nitrate is also consistent with an AHW nitrate $\delta^{15} \mathrm{~N}$ of around $5 \%$.

In summary, the above arguments indicate that high-latitude North Atlantic Ocean and AHW $\delta^{15} \mathrm{~N}_{\text {nitrate }}$ over the past 35,000 years was probably not less than the modern value of $5 \%$, and, if anything, may have been slightly higher than $5 \%$ o before the Holocene due to reduced subtropical North Atlantic $\mathrm{N}_{2}$ fixation ${ }^{71,88}$. Any such increase in AHW $\delta^{15} \mathrm{~N}_{\text {nitrate }}$ before the Holocene is in the opposite sense of the dominant change in our $\delta^{15} \mathrm{~N}_{\text {N.p. }}$ records, in which $\delta^{15} \mathrm{~N}_{\text {N.p. }}$ rises from Marine Isotope Stage 2 to the Holocene (Fig. 3 ).

Holocene $\boldsymbol{\delta}^{15} \mathbf{N}_{\text {N.p. }}$ and Pacific water inflow. At western Arctic sites B8 and B17, $\delta^{15} \mathrm{~N}_{N, p}$ varies between 7.7 and $8.7 \%$ o from 11 ka to the coretop (Fig. 3a). These variations, despite being modest, may indicate changes in the position of the PHWAHW front associated with varying input of Pacific water to the Arctic. At site B8, which presumably is most sensitive to Pacific water input due to its proximity to the Bering Strait (Fig. 1a), two intervals of elevated $\delta^{15} \mathrm{~N}_{\text {N.p. }}$ values occurred between $8-7 \mathrm{ka}$ and $6-5 \mathrm{ka}$. These times correspond to higher reconstructed phytoplankton productivity from opal and brassicasterol mass-accumulation rates, and to reduced sea-ice extent as demonstrated by reduced values of the phytoplankton marker-IP ${ }_{25}$ index $\left(\mathrm{PIP}_{25}\right)$, at a core location proximal to the Bering Strait in the Chukchi Sea ${ }^{91}$. These biomarker charges are argued to reflect two intervals of enhanced Pacific water inflow to the Arctic Ocean ${ }^{91}$. We propose that enhanced Pacific water input during these intervals shifted the position of the Pacific-Atlantic halocline front ${ }^{18}$, leading to an increased presence of PHW at site B8, higher $\delta^{15} \mathrm{~N}_{\text {nitrate }}$ and thus higher $\delta^{15} \mathrm{~N}_{\text {N.p. }}$ under conditions of complete nitrate consumption. A late Holocene reduction of Pacific water input is further supported by the coeval $\delta^{15} \mathrm{~N}_{\text {N.p. }}$ decline at site B17 after $5 \mathrm{ka}$ (Fig. 3).

\section{Data availability}

Source data are provided with this paper. Foraminifera-bound nitrogen isotope data are available from the NCEI Paleoceanography database (https://www.ncdc. noaa.gov/paleo-search/study/33272). Arctic Ocean seawater nitrate isotope data are available from BCO-DMO (https://www.bco-dmo.org/dataset/733109/data).

\section{References}

53. Darby, D. A., Bischof, J. F. \& Jones, G. A. Radiocarbon chronology of depositional regimes in the western Arctic Ocean. Deep Sea Res. 2 44, 1745-1757 (1997).
54. Poore, R. Z., Ostermann, D. R. \& McGeehin, J. Stable Isotope Data and AMS ${ }^{14}$ C Dates from Arctic Ocean Section 1994 Surface Sediment Transect and Box Core Samples from the Mendeleyev Ridge Area (US Geological Survey, 1999).

55. Poirier, R. K., Cronin, T. M., Briggs, W. M. Jr. \& Lockwood, R. Central Arctic paleoceanography for the last $50 \mathrm{kyr}$ based on ostracode faunal assemblages. Mar. Micropaleontol. 88-89, 65-76 (2012).

56. Heaton, T. J. et al. Marine20 - the marine radiocarbon age calibration curve (0-55,000 cal BP). Radiocarbon 62, 779-820 (2020).

57. Butzin, M., Köhler, P. \& Lohmann, G. Marine radiocarbon reservoir age simulations for the past 50,000 years. Geophys. Res. Lett. 44, 8473-8480 (2017).

58. Hanslik, D. et al. Quaternary Arctic Ocean sea ice variations and radiocarbon reservoir age corrections. Quat. Sci. Rev. 29, 3430-3441 (2010).

59. Blaauw, M. \& Christen, J. A. Flexible paleoclimate age-depth models using an autoregressive gamma process. Bayesian Anal. 6, 457-474 (2011).

60. Brooks, S. P. \& Gelman, A. General methods for monitoring convergence of iterative simulations. J. Comput. Graph. Stat. 7, 434-455 (1998).

61. Polyak, L. et al. Late Quaternary stratigraphy and sedimentation patterns in the western Arctic Ocean. Global Planet. Change 68, 5-17 (2009).

62. Granger, J. \& Sigman, D. M. Removal of nitrate with sulfamic acid for nitrate $\mathrm{N}$ and $\mathrm{O}$ isotope analysis with the denitrifier method. Rapid Commun. Mass Spectrom. 23, 3753-3762 (2009).

63. Sigman, D. M. et al. A bacterial method for the nitrogen isotopic analysis of nitrate in seawater and freshwater. Anal. Chem. 73, 4145-4153 (2001).

64. Casciotti, K. L., Sigman, D. M., Hastings, M. G., Böhlke, J. K. \& Hilkert, A. Measurement of the oxygen isotopic composition of nitrate in seawater and freshwater using the denitrifier method. Anal. Chem. 74, 4905-4912 (2002).

65. McIlvin, M. R. \& Casciotti, K. L. Technical updates to the bacterial method for nitrate isotope analyses. Anal. Chem. 83, 1850-1856 (2011).

66. Ren, H. et al. Impact of glacial/interglacial sea level change on the ocean nitrogen cycle. Proc. Natl Acad. Sci. USA 114, E6759-E6766 (2017)

67. Kast, E. R. et al. Nitrogen isotope evidence for expanded ocean suboxia in the early Cenozoic. Science 364, 386-389 (2019).

68. Knapp, A. N., Sigman, D. M. \& Lipschultz, F. N isotopic composition of dissolved organic nitrogen and nitrate at the Bermuda Atlantic time-series study site. Global Biogeochem. Cycles 19, GB1018 (2005).

69. Weigand, M. A., Foriel, J., Barnett, B., Oleynik, S. \& Sigman, D. M. Updates to instrumentation and protocols for isotopic analysis of nitrate by the denitrifier method. Rapid Commun. Mass Spectrom. 30, 1365-1383 (2016).

70. Robinson, R. S. et al. A review of nitrogen isotopic alteration in marine sediments. Paleoceanography 27, PA4203 (2012).

71. Ren, H. et al. Foraminiferal isotope evidence of reduced nitrogen fixation in the ice age Atlantic. Ocean Sci. 323, 244-248 (2009).

72. Schubert, C. J. \& Calvert, S. E. Nitrogen and carbon isotopic composition of marine and terrestrial organic matter in Arctic Ocean sediments: implications for nutrient utilization and organic matter composition. Deep Sea Res. 148 , 789-810 (2001).

73. Schubert, C. J., Stein, R. \& Calvert, S. E. Tracking nutrient and productivity variations over the last deglaciation in the Arctic Ocean. Paleoceanography 16, 199-211 (2001).

74. Nørgaard-Pedersen, N., Spielhagen, R. F., Thiede, J. \& Kassens, H. Central Arctic surface ocean environment during the past 80,000 years. Paleoceanography 13, 193-204 (1998).

75. Naidu, A. S. et al. Organic carbon isotope ratios of Arctic Amerasian continental shelf sediments. Int. J. Earth Sci. 89, 522-532 (2000).

76. Thibodeau, B., Bauch, D. \& Voss, M. Nitrogen dynamic in Eurasian coastal Arctic ecosystem: insight from nitrogen isotope. Global Biogeochem. Cycles 31, 836-849 (2017).

77. Wada, E. \& Hittori, A. Nitrogen isotope effects in the assimilation of inorganic nitrogenous compounds by marine diatoms. Geomicrobiol. J. 1, 85-101 (1978).

78. Sigman, D. M., Altabet, M. A., McCorkle, D. C., Francois, R. \& Fischer, G. The $\delta^{15} \mathrm{~N}$ of nitrate in the Southern Ocean: nitrate consumption in surface waters. Global Biogeochem. Cycles 13, 1149-1166 (1999).

79. Mariotti, A. et al. Experimental determination of nitrogen kinetic isotope fractionation: some principles; illustration for the denitrification and nitrification processes. Plant Soil 62, 413-430 (1981).

80. Ren, H. et al. Glacial-to-interglacial changes in nitrate supply and consumption in the subarctic North Pacific from microfossil-bound $\mathrm{N}$ isotopes at two trophic levels. Paleoceanography 30, 1217-1232 (2015).

81. Sigman, D. M. \& Fripiat, F. in Encyclopedia of Ocean Sciences 3rd edn, Vol. 1 (eds Cochran, J. K. et al.) 263-278 (Elsevier, 2019).

82. Fripiat, F. et al. The isotope effect of nitrate assimilation in the Antarctic Zone: improved estimates and paleoceanographic implications. Geochim. Cosmochim. Acta 247, 261-279 (2019).

83. Ren, H., Sigman, D. M., Thunell, R. C. \& Prokopenko, M. G. Nitrogen isotopic composition of planktonic foraminifera from the modern ocean and recent sediments. Limnol. Oceanogr. 57, 1011-1024 (2012). 
84. Smart, S. et al. Ground-truthing the planktic foraminifer-bound nitrogen isotope paleo-proxy in the Sargasso Sea. Geochim. Cosmochim. Acta 235, 463-482 (2018).

85. Kohfeld, K. E., Fairbanks, R. G., Smith, S. L. \& Walsh, I. D. Neogloboquadrina pachyderma (sinistral coiling) as paleoceanographic tracers in polar oceans: evidence from northeast water polynya plankton tows, sediment traps, and surface sediments. Paleoceanography 11, 679-699 (1996).

86. Marconi, D. et al. Nitrate isotope distributions on the US GEOTRACES North Atlantic cross-basin section: signals of polar nitrate sources and low latitude nitrogen cycling. Mar. Chem. 177, 143-156 (2015).

87. Knapp, A. N., DiFiore, P. J., Deutsch, C., Sigman, D. M. \& Lipschultz, F Nitrate isotopic composition between Bermuda and Puerto Rico: implications for $\mathrm{N}_{2}$ fixation in the Atlantic Ocean. Global Biogeochem. Cycles 22, GB3014 (2008).

88. Straub, M. et al. Changes in North Atlantic nitrogen fixation controlled by ocean circulation. Nature 501, 200-203 (2013).

89. Martínez-García, A. et al. Iron fertilization of the subantarctic ocean during the Last Ice Age. Science 343, 1347 (2014).

90. Auderset, A. Nutrient Cycling in the Oligotrophic Ocean Over the Past 65 Million Years Ch. $3 \mathrm{PhD}$ thesis, ETH Zurich (2020).

91. Stein, R. et al. Holocene variability in sea ice cover, primary production, and Pacific-Water inflow and climate change in the Chukchi and East Siberian Seas (Arctic Ocean). J. Quat. Sci. 32, 362-379 (2017).

92. Müller, J. et al. Holocene cooling culminates in sea ice oscillations in Fram Strait. Quat. Sci. Rev. 47, 1-14 (2012).

93. Cronin, T. M. et al. Quaternary sea-ice history in the Arctic Ocean based on a new ostracode sea-ice proxy. Quat. Sci. Rev. 29, 3415-3429 (2010).

\section{Acknowledgements}

We thank S. Oleynik, F. Rubach and L. Gemery for laboratory assistance, and L. Keigwin A. de Vernal and T. Pico for sharing data. J.R.F., F.F., A.M.-G. and G.H.H. were funded by the Max Planck Society. J.R.F., D.M.S. and O.M.U. also received support from US National Science Foundation grants OPP-0612198 and OCE-1536368, the Tuttle Fund of the Department of Geosciences of Princeton University, the Grand Challenges Program of the Princeton Environmental Institute and from ExxonMobil through the Andlinger Center for Energy and the Environment of Princeton University. J.G. was funded by US National Science Foundation grant OCE-1535002. T.M.C. was funded by the USGS Land Change Program. Any use of trade, firm or product names is for descriptive purposes only and does not imply endorsement by the US Government.

\section{Author contributions}

J.R.F., D.M.S. and J.G. designed the study; J.R.F. and O.M.U. performed the $\delta^{15} \mathrm{~N}_{\text {N.p. }}$ analyses; J.G. performed the seawater nitrate $\delta^{15} \mathrm{~N}$ analyses; T.M.C. provided the sediment samples; J.R.F., O.M.U. and T.M.C. provided chronology; J.R.F. and D.M.S. drafted the first version of the manuscript; all authors contributed to the interpretation of the data and preparation of the final manuscript.

\section{Funding}

Open access funding provided by Max Planck Institute for Chemistry (2).

\section{Competing interests}

The authors declare no competing interests.

\section{Additional information}

Extended data is available for this paper at https://doi.org/10.1038/s41561-021-00789-y.

Supplementary information The online version contains supplementary material available at https://doi.org/10.1038/s41561-021-00789-y.

Correspondence and requests for materials should be addressed to J.R.F.

Peer review information Nature Geoscience thanks Brian Haley, Sofia Ribeiro and the other, anonymous, reviewer(s) for their contribution to the peer review of this work. Primary Handling Editor: James Super.

Reprints and permissions information is available at www.nature.com/reprints. 

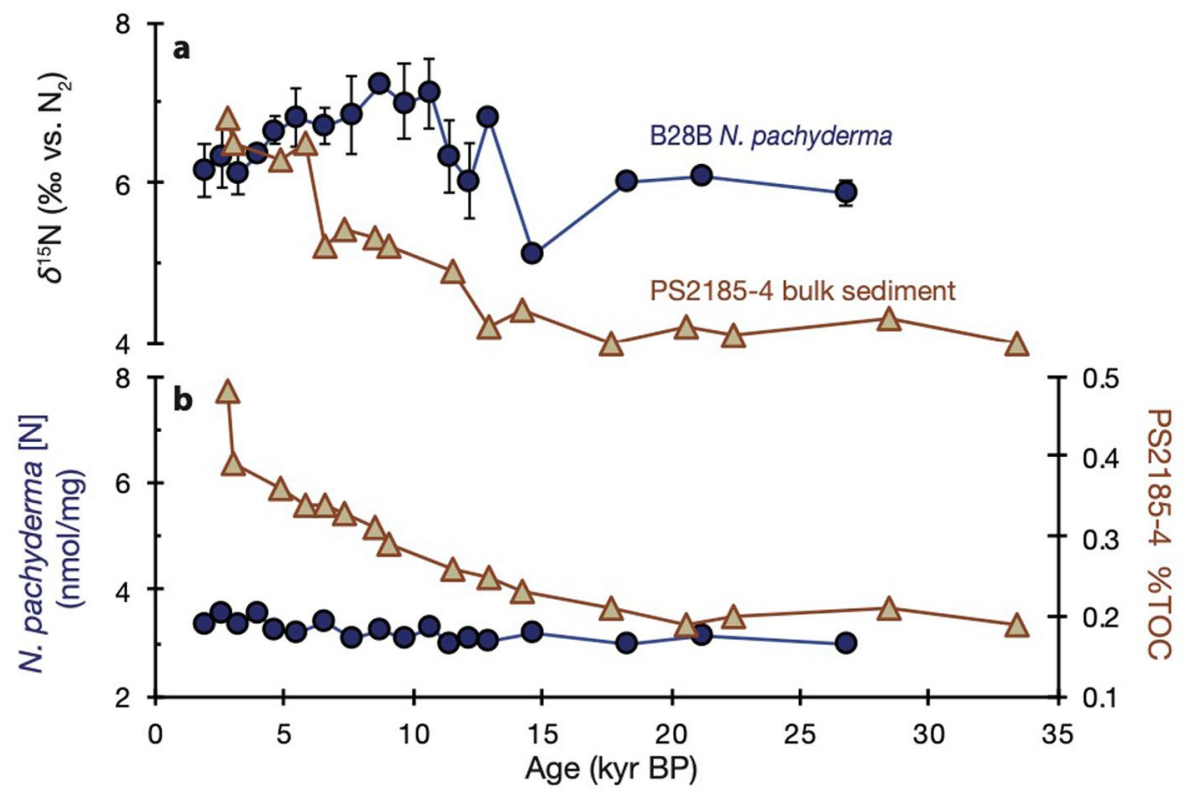

Extended Data Fig. 1 | Comparison of $\delta^{15} \mathrm{~N}_{\text {N.p. }}$ and $\mathrm{N}$ content from Site B28 (blue circles, this study) and bulk sediment $\delta^{15} \mathrm{~N}$ and $\%$ TOC from Site PS2185-4 (brown triangles, ref. ${ }^{73}$ ). a, Prior to $15 \mathrm{ka}$, bulk sediment $\delta^{15} \mathrm{~N}$ averages $4.1 \%$, which is 1.5 to $2 \%$ o lower than $\delta^{15} \mathrm{~N}_{\mathrm{N} . \mathrm{p} .}$. Between 15 and $10 \mathrm{ka}$, bulk sediment $\delta^{15} \mathrm{~N}$ increases by $1 \%$ while $\delta^{15} \mathrm{~N}_{\text {N.p. }}$ increases by $2 \%$; the high $\delta^{15} \mathrm{~N}_{\mathrm{N} . p \text {. }}$ at $13 \mathrm{ka}$ is absent in bulk sediment $\delta^{15} \mathrm{~N}$. Between 10 and $5 \mathrm{ka}$, bulk sediment $\delta^{15} \mathrm{~N}$ continues to increase, including a rapid $1.5 \%$ increase between 6 and $5 \mathrm{ka}$; in contrast, $\delta^{15} \mathrm{~N}_{\text {N.p. }}$ is constant through this time. After $5 \mathrm{ka}, \delta^{15} \mathrm{~N}_{\text {N.p. }}$ declines by $\sim$ \%o while bulk sediment $\delta^{15} \mathrm{~N}$ is constant. b, N. pachyderma N content is constant whereas PS2185-4 percent total organic carbon (\%TOC) declines downcore. The decline in bulk sediment \%TOC might reflect progressive diagenetic organic matter loss with depth, with terrestrial organic carbon being more recalcitrant. 


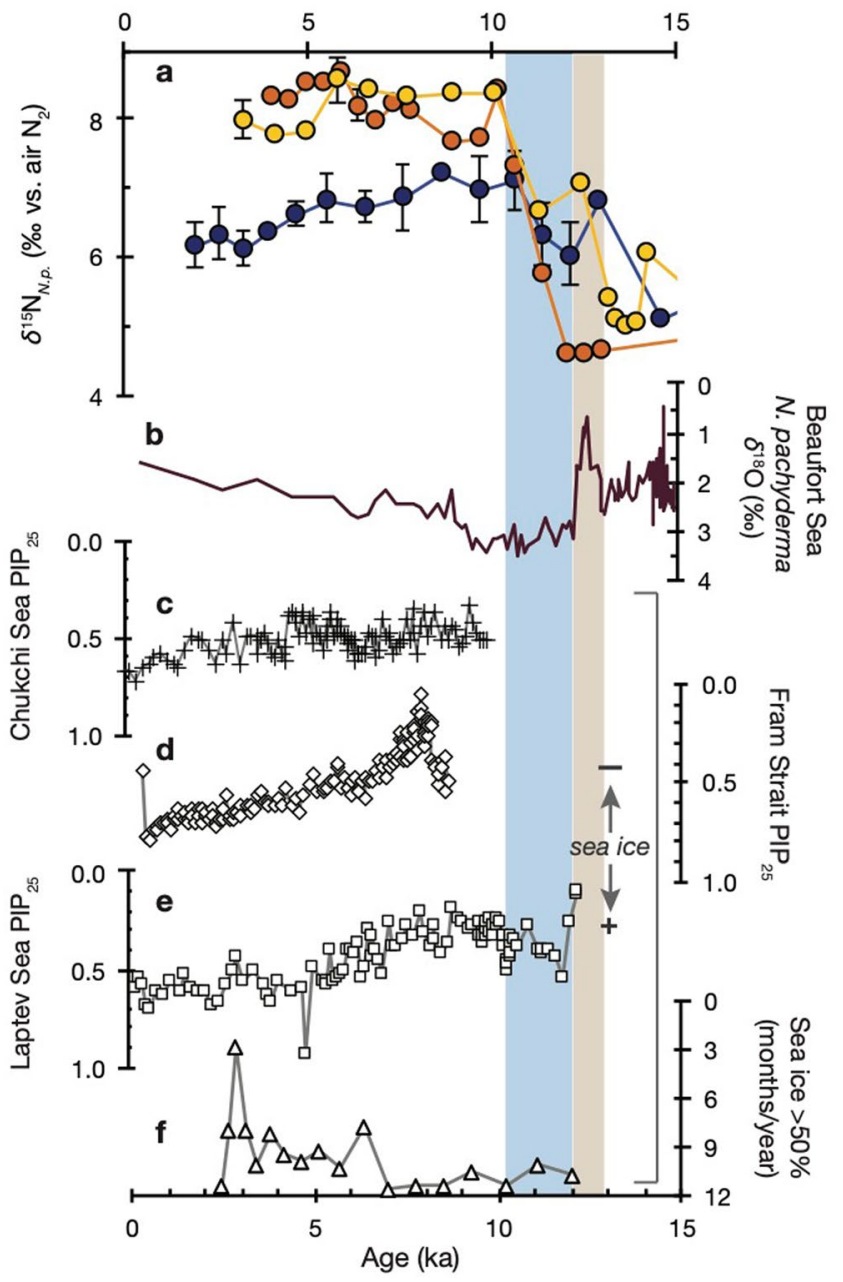

Extended Data Fig. 2 | Comparison to meltwater discharge and sea ice proxies. a, Arctic $\delta^{15} \mathrm{~N}_{\text {N.p. }}$ (colors as in Fig. 3), (b) N. pachyderma $\delta^{18} \mathrm{O}$ from the Beaufort Slope indicating freshwater flooding events in the Arctic Ocean ${ }^{36}$; greater freshwater discharge is upward. (c)-(f) Relative sea ice extent from c-e, $\mathrm{PIP}_{25}$ biomarker index in the (c) Chukchi Sea ${ }^{91}$, (d) Fram Strait ${ }^{92}$, (e) Laptev Sea ${ }^{45}$, and (f) open western Arctic Ocean sea ice coverage (months/year $>50 \%$ ) from dinocyst assemblages ${ }^{40}$ (locations in Fig. 1a). More extensive sea ice is downward. Vertical brown bar denotes the Younger Dryas; vertical blue bar indicates proposed timing of postglacial Bering Strait flooding ${ }^{33,34}$. 

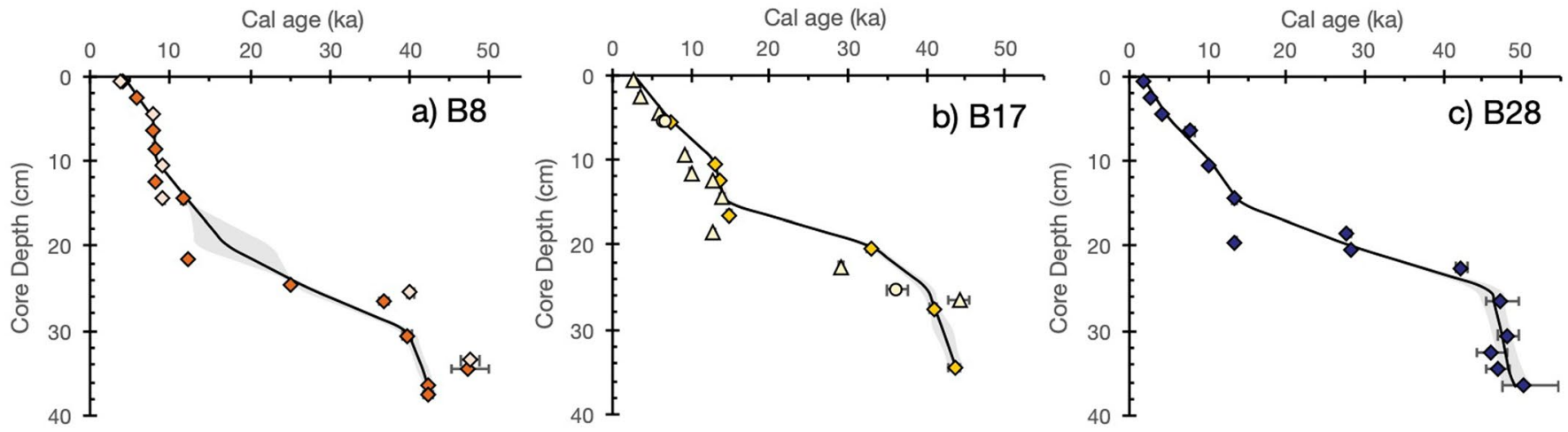

Extended Data Fig. 3 | Age models. Age-depth models for sediment cores B8 (a), B17 (b) and B28 (c). Black line in each panel is Bayesian age-depth model from Bacon ${ }^{59}$; gray shading indicates $95 \%$ confidence interval. Symbols indicate calibrated ${ }^{14} \mathrm{C}$ dates on N. pachyderma. Data sources: a) dark diamonds ${ }^{54}$, light diamonds ${ }^{55}$; b) diamonds ${ }^{54}$, triangles ${ }^{53}$, circles $^{93} ;$ c) diamonds ${ }^{53}$. 

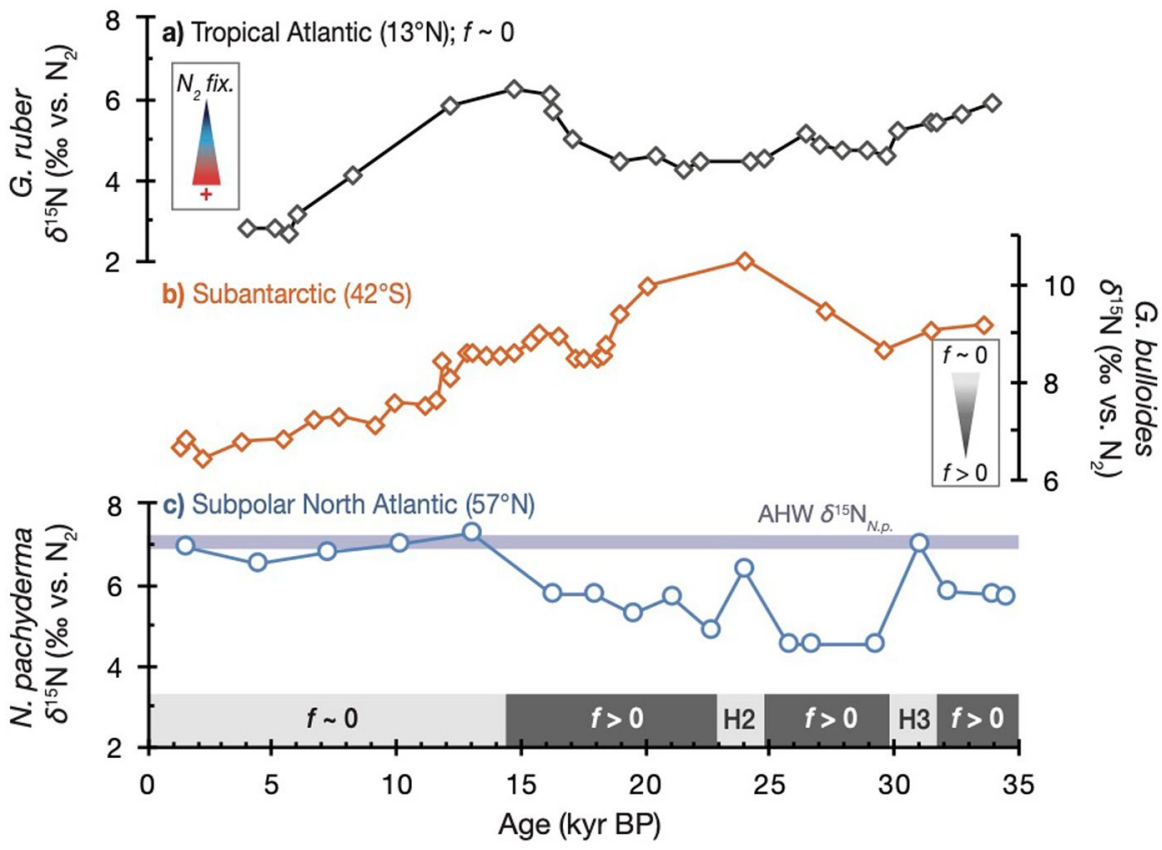

Extended Data Fig. 4 | Foraminifera-bound $\delta^{15} \mathrm{~N}$ constraints on AHW nitrate $\delta^{15} \mathrm{~N}$ over the last 35,000 years. a, $\delta^{15} \mathrm{~N}$ from the tropical Atlantic, with higher values indicating weaker $\mathrm{N}_{2}$ fixation during the last ice age ${ }^{71,88} \cdot \mathbf{b}, \delta^{15} \mathrm{~N}$ from the Subantarctic Southern Ocean, with higher values indicating more complete surface ocean nitrate consumption during the last ice age ${ }^{89} . \mathbf{c}, \delta^{15} \mathrm{~N}_{\text {N.p. }}$ from subpolar North Atlantic, interpreted in terms of changing nitrate consumption (dark gray bars at bottom); the data imply relatively constant $\delta^{15} \mathrm{~N}_{\text {nitrate }}$ if the Heinrich Stadial $\delta^{15} \mathrm{~N}_{\text {N.p. }}$ peaks reached complete consumption ${ }^{30}$ (light gray bars for Heinrich Stadials 2 and 3, compared with light gray bar for the Holocene). 


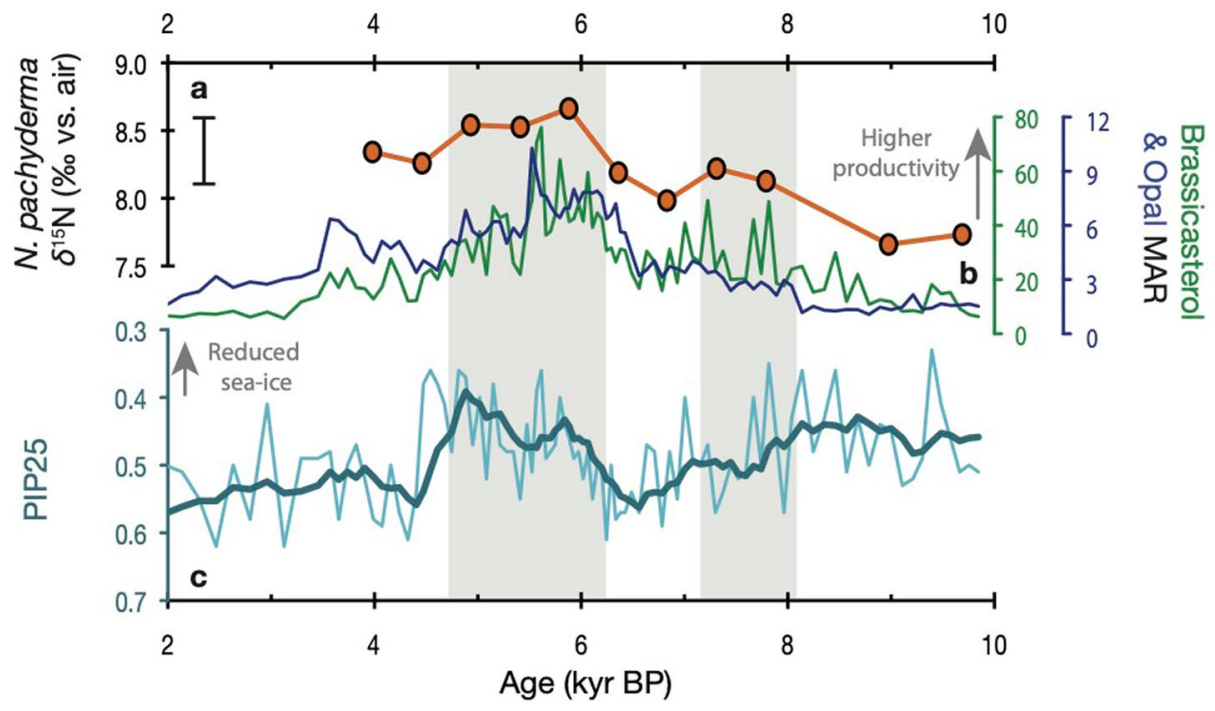

Extended Data Fig. 5 | Comparison to Holocene western Arctic productivity and sea ice proxies. a, Site B8 $\delta^{15} \mathrm{~N}_{\text {N.p. }}$ (orange circles), (b) Chukchi Sea phytoplankton productivity from brassicasterol (green) and opal (blue) mass accumulation rates and (c) Chukchi Sea sea ice extent from PIP 25 (blue) (ref. ${ }^{91}$ ). Higher brassicasterol and opal MARs indicate higher phytoplankton productivity; lower PIP $_{25}$ (plotted upward) indicates reduced sea ice extent. Gray shading denotes two intervals of higher Chukchi Sea productivity and reduced sea ice that have been attributed to increased Pacific water input to the Arctic Ocean ${ }^{91}$. 